\title{
Functional Analyses of the Diels-Alderase Gene sol5 of Ascochyta rabiei and Alternaria solani Indicate that the Solanapyrone Phytotoxins Are Not Required for Pathogenicity
}

\author{
Wonyong Kim, ${ }^{1}$ Chung-Min Park, ${ }^{2}$ Jeong-Jin Park, ${ }^{3}$ Hajime O. Akamatsu, ${ }^{1}$ Tobin L. Peever, ${ }^{1}$ Ming Xian, ${ }^{2}$ \\ David R. Gang, ${ }^{3}$ George Vandemark, ${ }^{1,4}$ and Weidong Chen ${ }^{1,4}$ \\ ${ }^{1}$ Department of Plant Pathology, ${ }^{2}$ Department of Chemistry, and ${ }^{3}$ Institute of Biological Chemistry, Washington State University, \\ Pullman 99164, U.S.A.; and ${ }^{4}$ United States Department of Agriculture-Agricultural Research Service, Grain Legume Genetics \\ and Physiology Research Unit, Washington State University, Pullman
}

Submitted 7 August 2014. Accepted 24 October 2014.

\begin{abstract}
Ascochyta rabiei and Alternaria solani, the causal agents of Ascochyta blight of chickpea (Cicer arietinum) and early blight of potato (Solanum tuberosum), respectively, produce a set of phytotoxic compounds including solanapyrones $\mathrm{A}, \mathrm{B}$, and $\mathrm{C}$. Although both the phytotoxicity of solanapyrones and their universal production among field isolates have been documented, the role of solanapyrones in pathogenicity is not well understood. Here, we report the functional characterization of the sol5 gene, which encodes a Diels-Alderase that catalyzes the final step of solanapyrone biosynthesis. Deletion of sol5 in both Ascochyta rabiei and Alternaria solani completely prevented production of solanapyrones and led to accumulation of the immediate precursor compound, prosolanapyrone II-diol, which is not toxic to plants. Deletion of sol5 did not negatively affect growth rate or spore production in vitro, and led to overexpression of the other solanapyrone biosynthesis genes, suggesting a possible feedback regulation mechanism. Phytotoxicity tests showed that solanapyrone $A$ is highly toxic to several legume species and Arabidopsis thaliana. Despite the apparent phytotoxicity of solanapyrone $A$, pathogenicity tests showed that solanapyrone-minus mutants of Ascochyta rabiei and Alternaria solani were equally virulent as their corresponding wild-type progenitors, suggesting that solanapyrones are not required for pathogenicity.
\end{abstract}

Ascochyta rabiei is a necrotrophic plant pathogenic fungus and causes Ascochyta blight of chickpea (Cicer arietinum L.).

The GenBank accession numbers of the Ascochyta rabiei sol4, sol5, actin1, and $\beta$-tubulin genes are KM244525, KM244526, KM244530, and KM244529, respectively.

Current address for H. O. Akamatsu: National Agriculture and Food Research Organization Agricultural Research Center (NARO/ARC), NARO, 3-1-1 Kannondai, Tsukuba, Ibaraki 305-8666, Japan.

Corresponding author: W. Chen; Telephone: +1.509.335.9178; Fax: +1.509.335.7692; E-mail: w-chen@wsu.edu

*The $e$-Xtra logo stands for "electronic extra" and indicates that seven supplementary figures and two supplementary tables are published online.

This article is in the public domain and not copyrightable. It may be freely reprinted with customary crediting of the source. The American Phytopathological Society, 2015.
The disease is manifested through necrotic lesions on all above ground tissues of the host plant (Cicer spp.) and may cause complete crop loss under conducive environmental conditions. Severe disease epidemics have been reported in various regions of the world (Nene 1982; Singh et al. 1984). The pathogen is known to produce polyketide-derived secondary metabolites, including solanapyrone A (SolA), solanapyrone B (SolB), and solanapyrone C (SolC) (Alam et al. 1989; Chen and Strange 1991). The same set of secondary metabolites were previously detected and identified in cultures of Alternaria solani, the causal agent of the early blight of potato and tomato (Ichihara et al. 1983).

All reliably identified Ascochyta rabiei isolates produce solanapyrones and their phytotoxicity has been investigated using chickpea cell suspension culture (Höhl et al. 1991; Latif et al. 1993) and detached or intact plants (Hamid and Strange 2000; Kaur 1995). In order to demonstrate involvement of the toxins in pathogenesis, efforts were made to correlate sensitivity of chickpea cultivars to the solanapyrone toxins with their susceptibility to the pathogen. A positive but nonsignificant correlation was detected among nine cultivars (Hamid and Strange 2000). Toxin production varies significantly by isolate and prolific solanapyrone producers tend to be more virulent (Kaur 1995). Although many studies have focused on the phytotoxicity of solanapyrones, the occurrence of solanapyrones during the infection process has not been demonstrated, and attempts to extract solanapyrones from infected plant tissues were unsuccessful (Höhl et al. 1991). Therefore, it has been proposed that the absence of solanapyrones in infected plants may be attributed to its rapid metabolism by host plants, and the ability to metabolize solanapyrones has been used as an indicator of host resistance to the disease (Bahti and Strange 2004; Hamid and Strange 2000).

Recently, the solanapyrone biosynthesis gene cluster was identified in Alternaria solani (Kasahara et al. 2010). The cluster comprises six genes (soll to sol6) covering approximately $20 \mathrm{~kb}$ of the genome. Among the six sol genes in the cluster, sol5 encodes a Diels-Alderase that catalyzes the final step of solanapyrone biosynthesis. Purified recombinant Sol5 protein was able to convert an in vitro synthesized precursor substrate, prosolanapyrone II, to SolA, demonstrating its involvement in both oxidation and the subsequent cyclization of the precursor compound via Diels-Alder reaction (Kasahara et al. 2010). The gene soll encodes a polyketide synthase (PKS) 
that initiates the solanapyrone biosynthesis pathway. Like many other secondary metabolite gene clusters, the solanapyrone gene cluster also includes a transcription factor-encoding gene (sol4). Roles of other sol genes-sol2 (an $\mathrm{O}$-methyltransferase), sol3 (a dehydrogenase), and sol6 (a cytochrome P450) — were tentatively assigned to the proposed biosynthetic scheme for solanapyrones (Kasahara et al. 2010).

Despite the strong phytotoxicity of solanapyrones, relatively little information is available on its mechanism of toxicity or the range of plants to which these compounds are phytotoxic. It was originally reported that SolA showed variable toxicity to a somaclonal population of potato ('Russet Burbank') in conjunction with an unidentified toxic compound in culture of Alternaria solani (Matern et al. 1978). Also, Kaur (1995) suggested solanapyrones as a host-selective toxin, with an observation that nonhost legumes of Ascochyta rabiei such as pea (Pisum sativum), cowpea (Vigna unguiculata), and green bean (Phaseolus vulgaris) were less sensitive to solanapyrones than chickpea. Both Ascochyta rabiei and Alternaria solani belong to the class Dothideomycetes, which includes all plant-pathogenic fungi that produce host-selective toxins (Turgeon and $\mathrm{Lu}$ 2000).

Host-selective toxins often target specific cellular components and may induce apoptosis (Tsuge et al. 2013; Walton 1996). SolA was shown to specifically bind to X-family DNA polymerases in vitro (Mizushina et al. 2002). This particular DNA polymerase family exerts its function exclusively on DNA repair processes during mitosis and meiosis (García-Díaz et al. 2000; Yamtich and Sweasy 2010). The mammalian genome possesses several different genes belonging to X-family DNA polymerase whereas, in higher plants, DNA polymerase $\lambda$ is the sole member of X-family DNA polymerase (Roy et al. 2009). Recently, it has become evident that proteins involved in DNA repair processes play crucial roles in the regulation of plant defense response (Song et al. 2011). Through a genetic screening of Arabidopsis thaliana mutants, several DNA repair proteins were characterized to be key components of plant immune signaling and defense gene expression (Durrant et al. 2007; Wang et al. 2010).

On the basis of its ability to cause disease on chickpea differentials, Ascochyta rabiei isolates can be broadly classified into two pathotypes named pathotype I (less virulent) or pathotype II (virulent) (Chen et al. 2004). However, recent studies of virulence in Ascochyta rabiei employing crosses between pathotype I and pathotype II isolates revealed that most of the progeny exhibited intermediate virulence, suggesting that virulence in Ascochyta rabiei is under polygenic control (Peever et al. 2012). No complete resistance to Asochyta blight has been reported in chickpea germplasm, and resistance to the pathogen is known to be controlled by quantitative trait loci (Iruela et al. 2006; Santra et al. 2000). The quantitative nature of both host resistance and pathogen virulence suggests that preformed or induced physical or chemical defense responses of the host plant and the subversion of these responses by the pathogen may be important determinants of the overall outcome (disease severity) of chickpea-Ascochyta rabiei interactions (Jayakumar et al. 2005).

Solanapyrones have long been considered to play a crucial role in pathogenicity or virulence, because solanapyrones are the sole chemical family of secondary metabolites with phytotoxic activities produced by Ascochyta rabiei. However, the role of the toxins in pathogenicity has not been critically examined. More recently, T-DNA insertion mutants that exhibited reduced solanapyrone production were generated via Agrobacteriummediated random mutagenesis. However, the mutants were not characterized with respect to the T-DNA insertion sites or pathogenicity (Mogensen et al. 2006). The recent identification of the solanapyrone biosynthesis gene cluster in Alternari solani allows us to examine the role of the toxins in both Ascochyta rabiei and Alternaria solani through the use of solanapyroneminus mutants generated with a targeted gene deletion approach.

The objectives of this study were to isolate solanapyrone toxins from Ascochyta rabiei and test their toxicity to host and selected nonhost plants, develop solanapyrone-minus mutants through targeted-gene replacement, and characterize the toxinminus mutants for growth and pathogenicity.

\section{RESULTS}

Solanapyrone biosynthesis gene cluster in Ascochyta rabiei.

Based on the DNA sequence of the solanapyrone biosynthesis gene cluster identified from Alternaria solani (GenBank accession AB514562) (Kasahara et al. 2010), we recovered an approximately 10-kb genomic DNA sequence through a homology-based polymerase chain reaction (PCR) approach. This DNA sequence included the full-length DNA sequences of sol5 and sol4 genes (GenBank accessions KM244526 and KM244525) coding for a solanapyrone synthase (a Diels-Alderase) and a putative transcription factor, respectively. Partial DNA sequences of other clustered genes (soll, sol2, sol3, and sol6) were also successfully amplified from Ascochyta rabiei genomic DNA (isolate AR628, ATCC 201622). The homologous sol5 DNA sequence and its deduced amino acid sequence were $97 \%$ identical to Alternaria solani sol5 (Supplementary Fig. S1). No obvious orthologs of sol5 were found in 61 complete or draft Dothideomycetes genome databases that include Didymella exigua, the type species of the genus Didymella (Grigoriev et al. 2014). All other genes in the cluster were approximately $97 \%$ similar between Ascochyta rabiei and Alternaria solani. This result showed that the solanapyrone gene clusters are highly conserved between the distantly related fungal species that belong to the families Didymellaceae (Ascochyta rabiei) and Pleosporaceae (Alternaria solani) in the class Dothideomycetes.

\section{Generation of solanapyrone-minus mutants.}

To study the role of solanapyrone toxins in pathogenicity, we generated solanapyrone-minus mutants from both Ascochyta rabiei and Alternaria solani by targeting the sol5 gene that catalyzes the final step of solanapyrone biosynthesis (Kasahara et al. 2010). For targeted sol5 gene deletion, three Ascochyta rabiei and two Alternaria solani isolates were used as progenitors (Table 1), and sol5 was deleted from the genomes using the gene replacement strategy illustrated in Supplementary Figure S2.

To check whether sol5-deletion $(\Delta$ sol5) mutants lost the ability to produce solanapyrones, we compared chemical profiles of culture extracts of $\Delta$ sols mutants with those of the wildtype progenitors. Liquid chromatography mass spectrometry (LC-MS) analysis of 18-day-old cultures of wild-type AR628 (Ascochyta rabiei) and ALS1 (Alternaria solani) isolates confirmed the production of SolA (eluted at $4.21 \mathrm{~min}$ ) and SolC (eluted at $4.03 \mathrm{~min}$ ) (Fig. 1B). Whereas SolA was a major component and consistently found in cultures, the amount of SolC production was highly variable from culture to culture and the timing of extraction, similar to previous observations for Alternaria solani (Oikawa et al. 1998b). Regardless of type of media and extraction method, SolB was never detected by a high-resolution ultrahigh-performance liquid chromatography tandem MS system (UPLC-MS) (Synapt G2, Waters Corp.) in cultures of Ascochyta rabiei or Alternaria solani in this study. Instead, a new peak (eluted at $4.32 \mathrm{~min}$ ) was detected in the chromatogram (Fig. 1B). The elemental composition and tandem mass analysis of the detected peak suggested that the 
compound was an oxidized form of SolA having the molecular formula $\mathrm{C}_{18} \mathrm{H}_{22} \mathrm{O}_{5}$ (discussed below). Structural identification of the compound is currently in progress. In $\Delta s o l 5$ culture extracts, there was no detectable solanapyrone production. Several new peaks were detected that were absent in the chromatograms of the wild-type culture extracts (Fig. 1B).

\section{Structural identification of the precursor compound in $\Delta$ sol5 mutants.}

To elucidate the structure of the commonly detected compound eluted at $2.26 \mathrm{~min}$ in the LC-MS analysis of $\Delta$ sol5 mutant cultures of Ascochyta rabiei and Alternaria solani (Fig. 1B), it was purified by preparative thin-layer chromatography (TLC), and subsequently analyzed using 1D and 2D NMR techniques. The correlation details among protons and between protons and carbons were illustrated in Supplementary Figure 3. Based on ${ }^{1} \mathrm{H}-{ }^{1} \mathrm{H}$ COSY spectrum and by interpretation of heteronuclear multiple bond correlation data (Supplementary Figs. 4 and 5), the compound was unambiguously identified as prosolanapyrone II-diol (Pros-II-diol), having the molecular formula $\mathrm{C}_{18} \mathrm{H}_{26} \mathrm{NaO}_{6}\left(\mathrm{~m} / \mathrm{z}=361.1[\mathrm{M}+\mathrm{Na}]^{+}\right)$(Fig. 1). This intensive spectrometric identification further confirmed the deletion of sol5 gene, which led to the accumulation of an oxidized form of prosolanapyrone II being used previously in in vitro synthesis of solanapyrones (Oikawa et al. 1998a).

\section{Solanapyrone biosynthesis gene expression and its feedback regulation.}

Ascochyta rabiei is known to produce solanapyrones during the onset of conidial sporulation (Höhl et al. 1991). To gain further insights into kinetics and the timing of solanapyrone production in culture, we investigated transcript levels of the key solanapyrone biosynthesis genes soll and sol5 involved in the first and the last steps of the solanapyrone biosynthesis pathway, respectively (Kasahara et al. 2010). As with secondary metabolite biosynthesis gene regulation in other fungi (Payne et al. 1993; Peplow et al. 2003), soll and sol5 appear to be coregulated, showing a similar expression pattern (Fig. 2A). Only trace amounts of transcripts were detected from young mycelia at 3 days post incubation (dpi). As the fungal colony become mature, the expression levels of soll and sol5 gradually increased, peaking at 12 or $15 \mathrm{dpi}$ when the fungal colonies were profusely sporulating followed by a reduction in expression thereafter. The kinetics of sol gene expression was consistent with the association of solanapyrone production with the conidiation process.

To examine the effect of sol5 deletion on the expression of other solanapyrone biosynthesis genes, transcript levels of sol genes (soll to sol6) were compared between AR628 and its $\Delta$ sol5. The sol5 gene deletion was confirmed by a complete lack of sol5 gene transcript in $\Delta$ sol5 (Fig. 2B). The sol5 gene seemed to not be efficiently spliced in the wild type because the premRNA band was of an intensity nearly equal to that of the mRNA band, although no premRNA band was detected in the reference gene, actinl. More interestingly, the reversetranscriptase (RT)-PCR analysis revealed that sol4 was markedly overexpressed in $\Delta$ sol5. Real-time RT-PCR analysis indicated that expression levels of soll and sol4 genes in $\Delta$ sol5 were approximately 5- and 25-fold higher, respectively, than in the wild type (Fig. 2C).

\section{Effect of solanapyrones on growth of Ascochyta rabiei and Alternaria solani.}

Although growth rates of Ascochyta rabiei and Alternaria solani differ greatly, wild-type isolates of Ascochyta rabiei and Alternaria solani both showed a restricted growth phenotype on nutrient-rich medium potato dextrose agar (PDA) (Fig. 3A). Growth rates of the wild-type strains gradually decreased as the colonies matured (Fig. 3B). In contrast, growth rates of $\Delta$ sol5 mutants were constant until they reached the edge of the agar plates (13.5 $\mathrm{cm}$ in diameter). Conidial morphology and timing of conidiation of the $\Delta$ sol5 were similar to their respective progenitors of either Ascochyta rabiei or Alternaria solani (data not shown). Ascochyta rabiei is an outcrossing fungal species requiring mating between two strains of opposite mating types to develop the sexual stage (D. rabiei) (Wilson and Kaiser 1995). The sexual stage (teleomorph) of Ascochyta rabiei was also successfully induced in the laboratory by

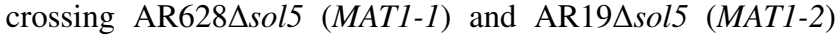
(Supplementary Fig. S6). Therefore, solanapyrone production does not appear to be required for normal growth and development or for sexual or asexual reproduction, thus fulfilling the criterion as secondary metabolites.

Phytotoxicity of solanapyrones on host and nonhost plants.

The phytotoxicity of solanapyrones to chickpea, the host of Ascochyta rabiei, has been well documented. However, the spectrum of the toxicity on different plant species and the mode of action remain largely unknown. Therefore, toxicity of SolA, SolC, and the precursor Pros-II-diol to host and nonhost legume species was evaluated. The compounds were purified from culture extracts of the wild type (AR628) or $\Delta$ sol5 mutant, and the purity and identities were verified via LC-MS analysis (Fig. 4). Among the tested compounds, only SolA showed significant phytotoxicity to all the tested plant species. Multiple comparisons of mean lesion size produced by a $3-\mu \mathrm{g}$ application of

Table 1. Isolates of Ascochyta rabiei and Alternaria solani used in this study

\begin{tabular}{|c|c|c|c|c|}
\hline Isolate and strain & Mating type $^{a}$ & Origin of isolation & Geographic location & Year of isolation \\
\hline \multicolumn{5}{|l|}{ Ascochyta rabiei } \\
\hline AR628WT (ATCC 201622) & MAT1-1 & Cicer arietinum & Syria & 1995 \\
\hline AR628 $\Delta$ sol5 & $\ldots$ & $\ldots$ & $\ldots$ & $\ldots$ \\
\hline AR628GFP (TEFprom::GFP) & $\ldots$ & $\ldots$ & $\ldots$ & $\ldots$ \\
\hline AR628GFP $\Delta$ sols & $\ldots$ & $\ldots$ & $\ldots$ & $\ldots$ \\
\hline AR21WT (ATCC 76502) & MAT1-1 & C. arietinum & Idaho, United States & 1986 \\
\hline AR21 1 sol5 & $\ldots$ & $\ldots$ & $\ldots$ & $\ldots$ \\
\hline AR19WT (ATCC 24891) & MAT1-2 & C. arietinum & Iran & 1990 \\
\hline AR19 19 sol5 & $\ldots$ & $\ldots$ & $\ldots$ & $\ldots$ \\
\hline \multicolumn{5}{|l|}{ Alternaria solani } \\
\hline ALS1WT & NA & Solanum tuberosum & Washington, United States & 2011 \\
\hline ALS1 $1 \Delta$ sol5 & $\ldots$ & $\ldots$ & $\ldots$ & $\ldots$ \\
\hline ALS2WT & NA & S. tuberosum & Idaho, United States & 2010 \\
\hline ALS2 2 sol5 & $\ldots$ & $\ldots$ & $\ldots$ & $\ldots$ \\
\hline
\end{tabular}


SolA $(1 \mu \mathrm{g} / \mu \mathrm{l}, 3 \mu \mathrm{l})$ showed no significant difference in sensitivity to the toxin among chickpea genotypes with varying disease resistance to Ascochyta blight (Fig. 5). SolC exhibited a moderate phytotoxic effect at the tested concentrations, while the precursor showed no toxic effect (Fig. 5). The solvent control (6\% methanol) did not produce any detectable necrosis. This result suggests that SolA is a major phytotoxic compound with nonhost selectivity.

Previously, SolA was shown to specifically bind to X-family DNA polymerases in vitro (Mizushina et al. 2002). To test whether SolA indeed targets the specific DNA polymerase such as DNA polymerase $\lambda$ (POLL), the sole member of $\mathrm{X}$-family DNA polymerase in plants (Roy et al. 2009), we utilized the model Arabidopsis system in which the modes of action of many fungal phytotoxins have been studied (Lorang et al. 2004; Nishiuchi et al. 2006; Stone et al. 2000). The seedling growth of Arabidopsis wild-type (Col-0 ecotype), POLL knockdown mutant $\left(P O L L^{K D}\right)$, and POLL overexpression transgenic plants $\left(P O L L^{O E}\right)$ were monitored on Murashige and Skoog agar amended with different concentrations of SolA. As the concentration of SolA increased, primary root growth was progressively restricted until it was completely inhibited at $60 \mu \mathrm{M}$ (Fig. 6A). Levels of inhibition were not significantly different among the tested Arabidopsis genotypes, suggesting that Arabidopsis POLL is unlikely the target of SolA. Intriguingly, whereas primary root growth was inhibited by SolA treatment, lateral root branching was induced by increasing the dose of SolA (Fig. 6B). The lateral root branching was not due to the inactivation of SolA over time because fresh seedlings exhibited the same phenotype on 10-dayold media containing $60 \mu \mathrm{M}$ SolA, indicating that this phenotype resulted from specific but as yet unknown actions of SolA.

\section{Solanapyrones not required for pathogenicity.}

The role of solanapyrones in pathogenicity of Ascochyta rabiei to chickpea was evaluated by comparing the diseasecausing abilities of $\Delta$ sol5 mutants with their respective progenitors, which include isolates of different pathotypes. Because the precursor (Pros-II-diol) that accumulated in the $\Delta$ sol5 mutant

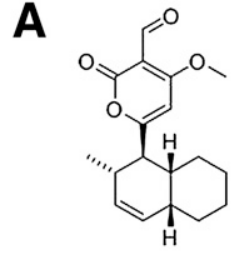

Solanapyrone A

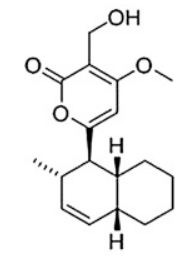

Solanapyrone B

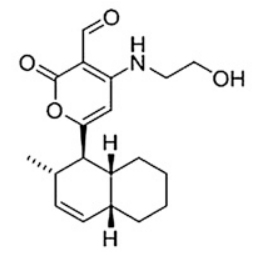

Solanapyrone C<smiles>COc1cc(/C=C/CCCC/C=C/[C@@H](O)C(C)O)oc(=O)c1CO</smiles>

Prosolanapyrone II-diol

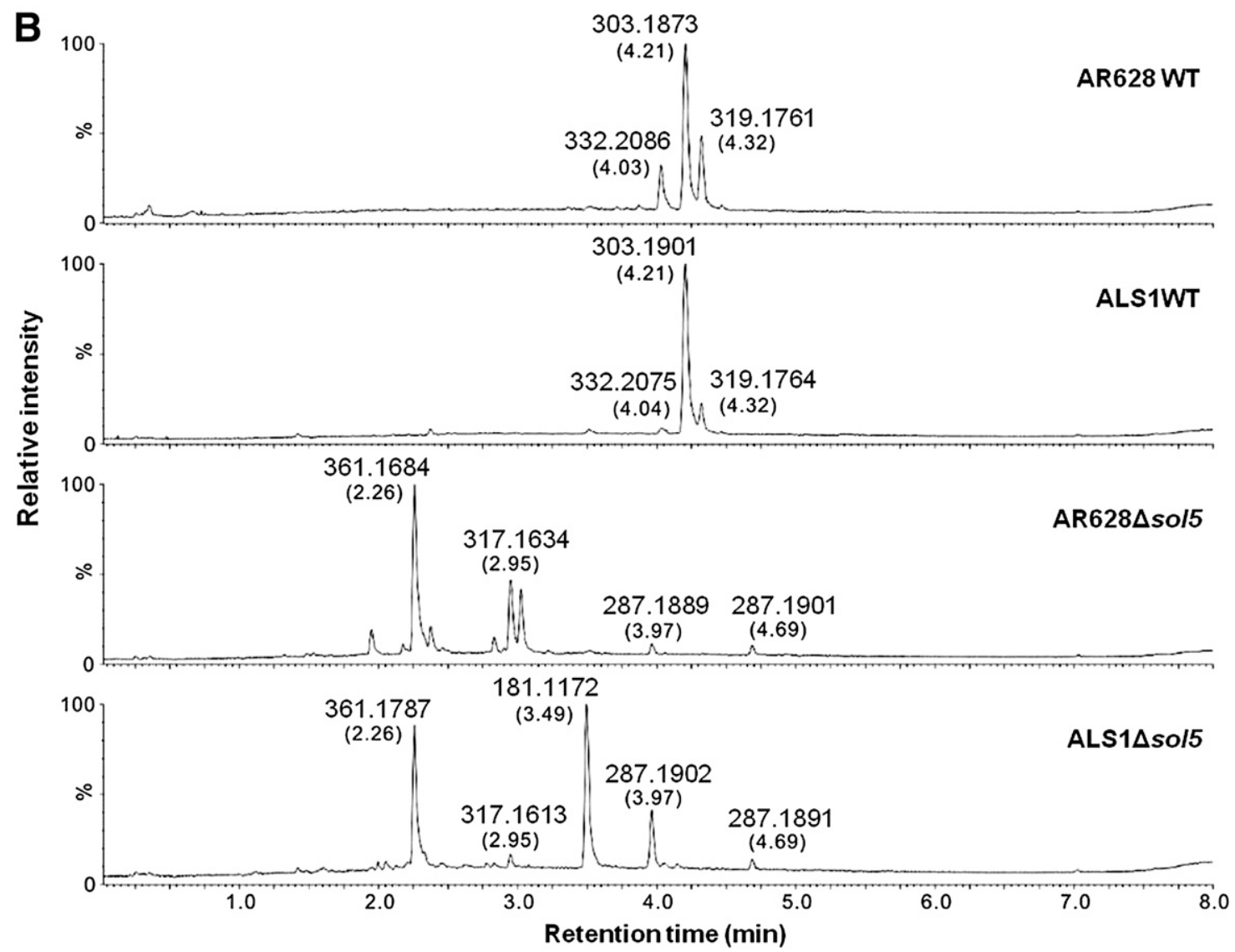

Fig. 1. Chemical structures and detection of metabolites in cultures of Ascochyta rabiei and Alternaria solani wild types (WT) and their $\Delta$ sol5 mutants A, Chemical structure of solanapyrones, and prosolanapyrone II-diol. B, Total ion chromatograms of equivalent quantities of culture extracts of isolates AR628 (Ascochyta rabiei), ALS1 (Alternaria solani), and the respective $\Delta$ sol5 mutants, indicated by observed $\mathrm{m} / \mathrm{z}$ values with their respective retention times (in parenthesis) for each compound at the peak. 
cultures did not show toxicity to plants, it is assumed that the precursor would not contribute to pathogenicity or virulence. Overall disease symptoms and severity caused by $\Delta$ sol5 mutants in susceptible 'Spanish White' and 'Dwelley' chickpea cultivars were not different from those caused by the wild-type strains (Fig. 7A). In addition, microscopic examination at the early stage of infection further confirmed that pathogenic behaviors of the $\Delta$ sol5 mutant were similar to the wild-type strain in terms of conidial germination, germ tube elongation on the leaf surface, and hyphal branching in the subepidermal layer at 1 to $2 \mathrm{dpi}$ (Fig. 7B).

Disease incidence rates of the wild type and $\Delta$ sol5 mutant were also evaluated by a coinoculation method on resistant 'CDC Frontier' (Vail and Banniza 2008). In the first experiment, the total number of lesions caused by the mutant was significantly higher than that caused by the wild type $(P=$ 0.030) (Table 2). However in the second experiment, there was no statistical difference in total number of lesions incited by the wild type or the $\Delta$ sol5 mutant $(P=0.479)$. The average length and number of lesions produced by the mutant was not different from those produced by the wild-type strains, based on Student's $t$ test (Table 2). The result demonstrated that the solanapyrone-minus mutant was equally virulent to chickpea regardless of the host genotype differing in the Ascochyta blight resistance.

With the Alternaria solani wild-type isolates and their corresponding $\Delta$ sols mutants, we also tested the involvement of solanapyrones in the Alternaria solani-potato or tomato pathosystems. The sizes of necrotic lesions incited by the $\Delta$ sol5 mutants were not significantly different from those incited by the wild-type strains on both potato and tomato (Table 3; Fig. 8).

Taken together, this series of pathogenicity tests with solanapyroneminus mutants provided evidence that solanapyrones are not required either for Ascochyta blight of chickpea or for early blight of potato or tomato.

\section{DISCUSSION}

Fungi produce a diverse array of secondary metabolites that show various biological activities. It is tempting to define the role of secondary metabolites produced by plant-pathogenic fungi as pathogenicity or virulence factors, especially when the chemical compounds exhibit toxicity (chlorosis or necrosis) to plant tissues when applied to plants independent of the pathogen. However, more direct evidence is needed before claiming that a compound is a pathogenicity factor, because the phytotoxicity
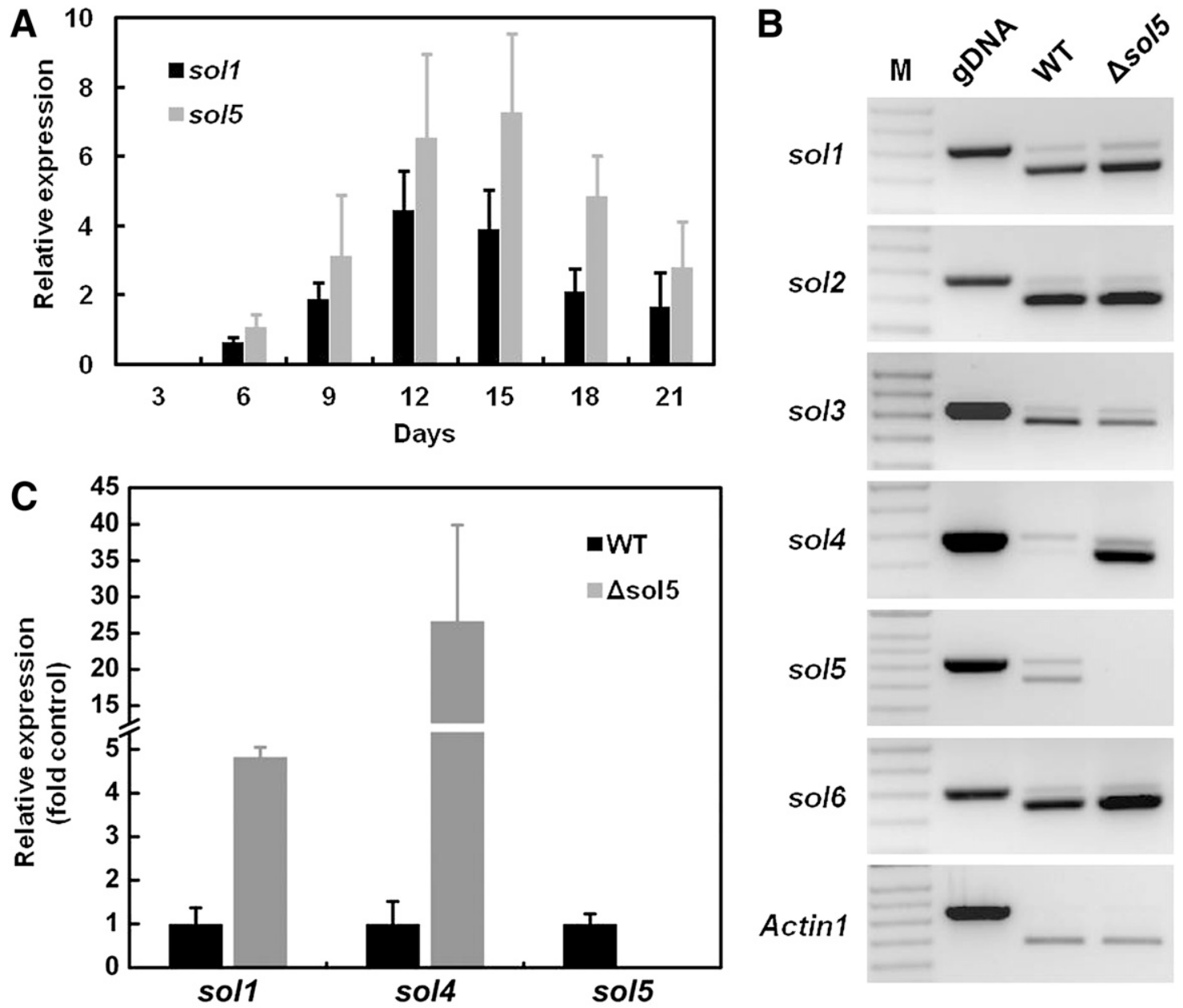

Fig. 2. Expression pattern of solanapyrone biosynthesis genes. A, Time-course gene expression levels of soll and sol5 in the wild-type (WT) strain AR628 of Ascochyta rabiei on potato dextrose agar (PDA). B, Comparison of expression levels of solanapyrone cluster genes (soll to sol6) between AR628 WT and its $\Delta$ sol5 mutant via reverse-transcriptase polymerase chain reaction (RT-PCR) analysis. Total RNA was extracted from 9-day-old colony grown on PDA. $\mathrm{M}=100$-bp DNA ladder marker. Total genomic DNA (gDNA) of the WT was used to compare PCR products from DNA (size differences were due to presence of an intron in genomic DNA). C, Relative expression levels of soll, sol4, and sol5 genes in the AR628 WT and its $\Delta$ sol5 mutant. Quantitative RT-PCR was performed and the gene expression of sol genes were normalized by actinl expression levels in respective samples. Error bars are standard deviation of three biological replicates. 
could arise from a nontarget effect of the test compound on living organisms. Here, we report generation of solanapyrone-minus mutants to elucidate the role of solanapyrones in pathogenicity. The resulting mutants all lacked the ability to produce solanapyrone and, instead, accumulated the immediate precursor that showed no apparent toxicity to plants. It has been reported that different genotypes of a given pathogen species may deploy different arsenals controlling disease development (Siewers et al. 2005). To rule out the possibility of strain-specific use of solanapyrones in pathogenicity, we generated solanapyrone-minus mutants from three Ascochyta rabiei isolates varying in virulence and geographic origin, as well as from two Alternaria solani isolates. A series of pathogenicity tests consistently showed that solanapyrone-minus mutants were all as virulent as their respective wild-type progenitors. We assumed that the precursors of solanapyrones play no roles in virulence, which was confirmed by targeted deletion of gene sol4, a transcription factor in the solanapyrone gene cluster. The sol4-deletion mutants produced neither solanapyrone nor the precursors found in $\Delta$ sol5 mutants, yet they were equally virulent on chickpea as their progenitors (W. Kim and W. Chen, unpublished results). These results strongly suggest that solanapyrones are not a virulence factor in either Ascochyta rabiei or Alternaria solani but may play an important role in other aspects of pathogen biology. Possible roles of solanapyrones in a saprobic growth stage will be discussed below.

\section{Evolutionary perspective on the origin}

of solanapyrone biosynthesis gene cluster.

Horizontal gene transfer (HGT) is defined as the movement of stable genetic material between different strains or species (Doolittle 1999). Recently, several HGT events of secondary metabolite gene clusters between fungi have been reported (Akagi et al. 2009; Khaldi and Wolfe 2011; Slot and Rokas 2011). The presence of a solanapyrone biosynthesis gene cluster in two different species, Ascochyta rabiei (Didymellaceae) and Alternaria solani (Pleosporaceae), suggests its acquisition by an HGT event between the two species or from
A
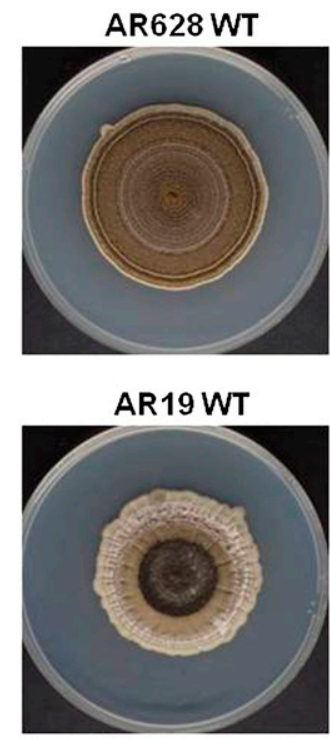

B
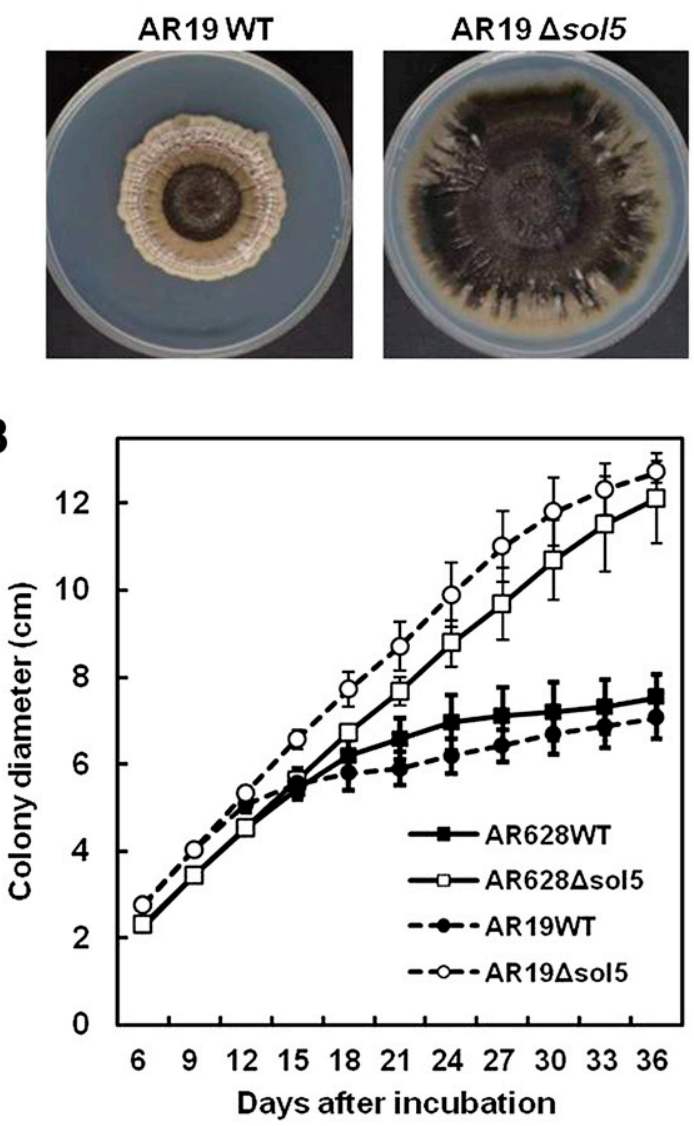

C

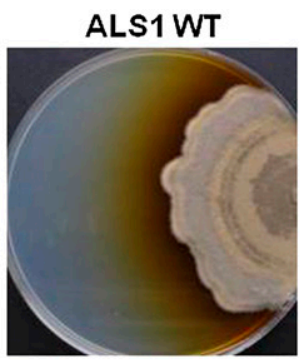

ALS2 WT

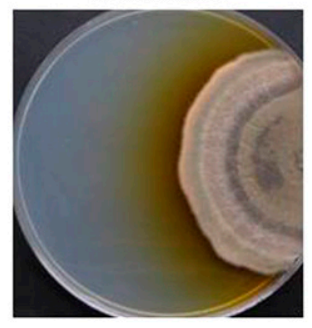

D

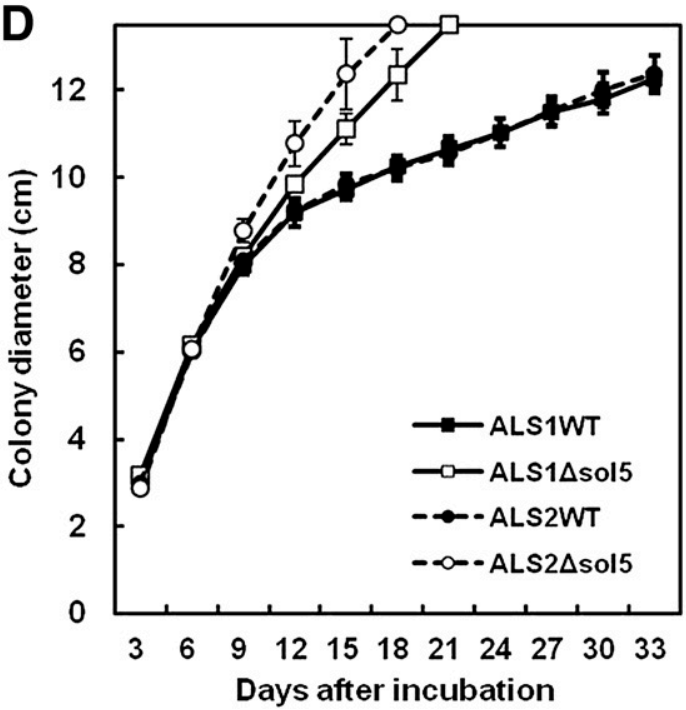

Fig. 3. Comparison of growth phenotypes of Ascochyta rabiei and Alternaria solani wild-type (WT) strains and their respective $\Delta$ sol5 mutants. A, Representative pictures of colony morphology of WT isolates AR628 and AR19 and their corresponding $\Delta$ sol5 mutants of Ascochyta rabiei 5 weeks after incubation on potato dextrose agar (PDA). B, Growth curves of the WT isolates and their corresponding $\Delta$ sol5 mutants on PDA. Error bars are standard deviation $(n=5)$. C, Representative pictures of colony morphology of WT isolates ALS1 and ALS2 and their corresponding $\Delta$ sol5 mutants of Alternaria solani 3 weeks after incubation on PDA. D, Growth curves of the WT isolates and their corresponding $\Delta$ sol5 mutants on PDA. 


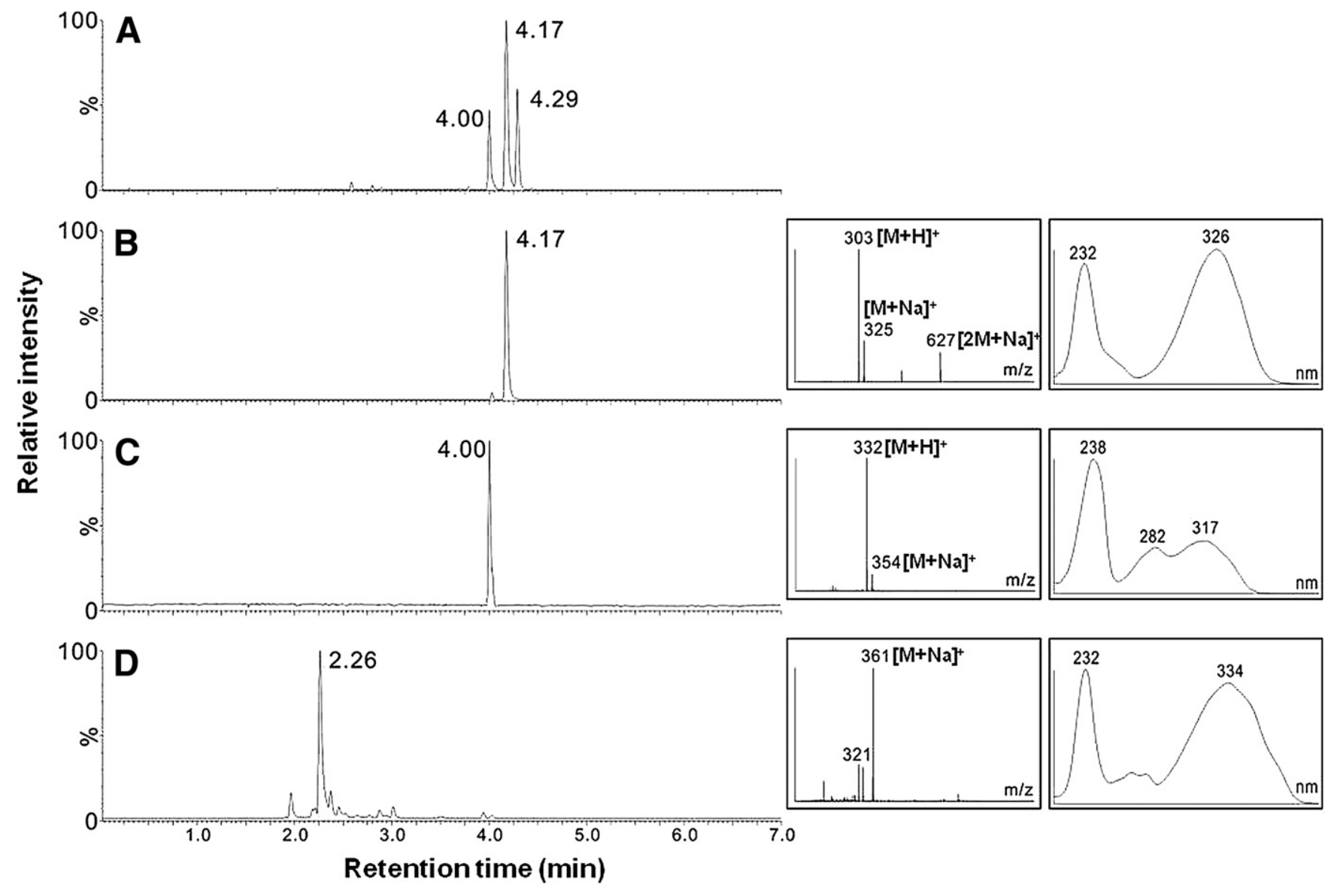

Fig. 4. Purification and verification of solanapyrones and the immediate precursor compound. A, Base peak ion chromatograms of culture extract of Ascochyta rabiei isolate AR628 grown on half strength potato dextrose broth; $\mathbf{B}, \mathbf{C}$, and $\mathbf{D}$, preparative thin-layer chromatography-purified solanapyrone A solanapyrone $\mathrm{C}$ from the wild-type strain and prosolanapyrone II-diol from the $\Delta$ sol5 mutant, respectively, with mass spectrum (insets, left) and UV spectrum (insets, right) for each purified compound at the peak.
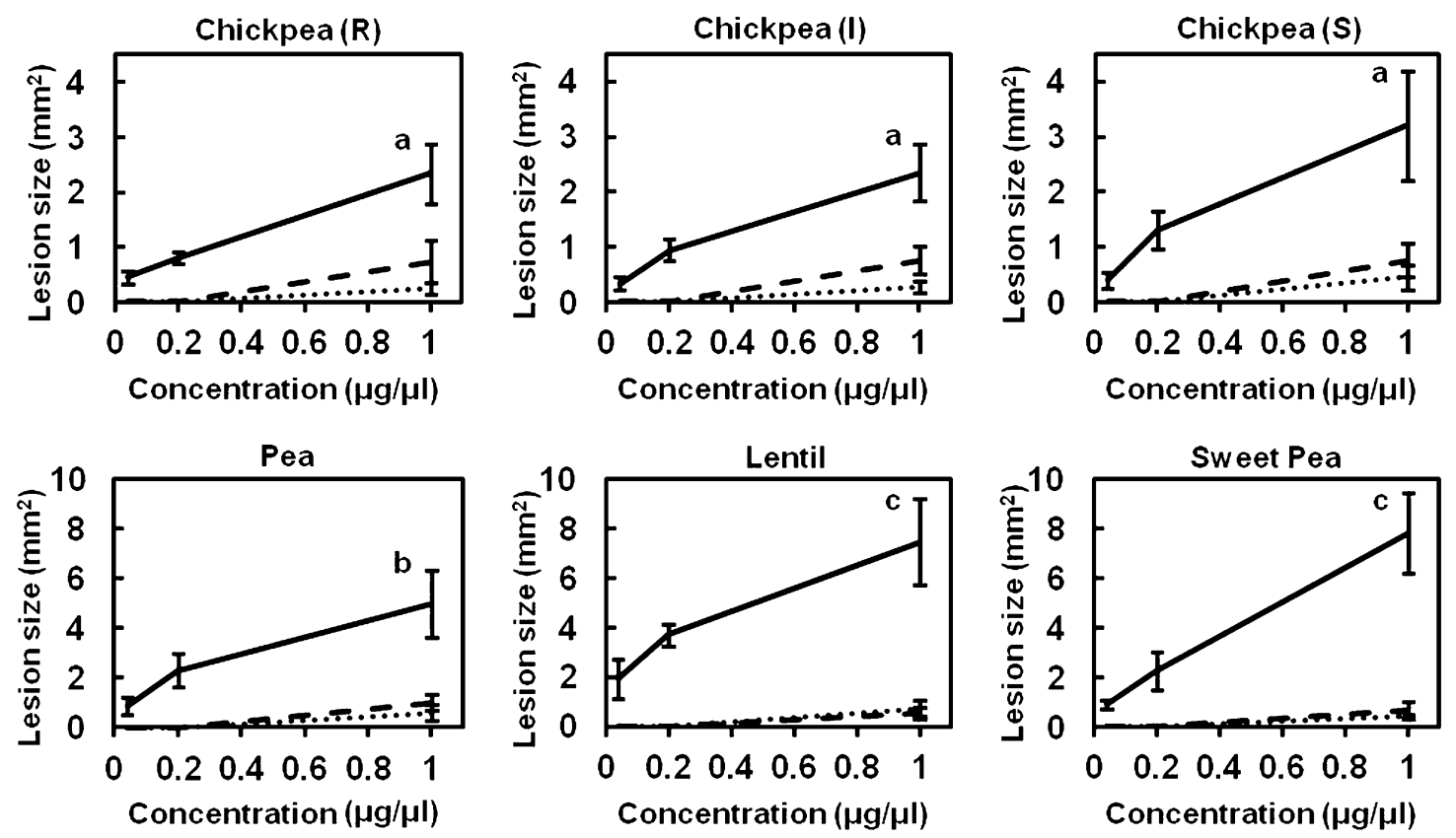

Fig. 5. Comparative analysis of phytotoxic effects of solanapyrones on legume species. Droplets $(3 \mu \mathrm{l})$ of different concentrations $(0.04,0.2$, or $1.0 \mu \mathrm{g} / \mu \mathrm{l})$ of the purified compounds were applied to pin-punctured wounds on leaflets. Necrotic areas produced by solanapyrone A (solid lines), solanapyrone C (dashed lines), and prosolanapyrone II-diol (dotted lines) 3 days after application. Different alphabetic letters indicate significant difference in mean lesion size produced on legumes by solanapyrone A at $1.0 \mu \mathrm{g} / \mu \mathrm{l}$ (least significant difference test using Bonferroni correction, $P \leq 0.05$ ). Bars represent standard deviation $(n=9$ to 12 ). Chickpea $(\mathrm{R})=$ resistant germplasm line W6 22589, Chickpea $(\mathrm{I})=$ intermediate resistant germplasm line FLIP 84-92C, Chickpea $(\mathrm{S})=$ susceptible chickpea Spanish White, Pea = Dark Skin Perfection $($ Pisum sativum), Lentil = Pardina (Lens culinaris), and Sweet Pea = Spencer-type mix (Lathyrus odoratus). 
a third organism independently. The DNA sequence identity of sol5 is over $97 \%$ between the two fungi. The similarity of these two genes was higher than those of housekeeping genes such as actinl (GenBank accessions KM244530 and JQ671723) and $\beta$-tubulin (GenBank accessions KM244529 and HQ413317), which showed 91 and $90 \%$ sequence identity, respectively, supporting the HGT hypothesis.

Genes involved in secondary metabolite biosynthesis, such as PKS and nonribosomal peptide synthetase, are known to evolve rapidly (Inderbitzin et al. 2010). For example, T-toxin and PMtoxin that have similar chemical structures and the same biological activity are produced by Cochliobolus heterostrophus (Pleosporaceae) and D. zeae-maydis (Didymellaceae) (Yoder 1973). The homologous PKS genes responsible for biosynthesis of T-toxin and PM-toxin showed only $60 \%$ DNA sequence identity, suggesting divergence of the gene from a common ancestor rather than HGT between the two species (Inderbitzin et al. 2010). Recently, genome sequence data of Ascochyta rabiei isolate AR628 showed that the orthologous soll genes of Ascochyta rabiei and Alternaria solani shared approximately $97 \%$ identity. This remarkably high degree of similarity may indicate that the solanapyrone biosynthesis gene cluster was horizontally transferred rather than vertically transmitted from a common ancestor of Ascochyta rabiei and Alternaria solani.

\section{Solanapyrone biochemistry.}

The sol5 gene encodes a Diels-Alderase that catalyzes the last step of solanapyrone biosynthesis. Diels-Alderase is a unique enzyme rarely found in nature and believed to be engaged in biosynthesis of commercially important chemicals such as lovastatin (a cholesterol-lowering drug) and spinosyn A (a potent insecticide) (Auclair et al. 2000; Kim et al. 2011). Sol5 is the first example of a naturally occurring Diels-Alderase (Katayama et al. 1998). The structural identification of the major metabolite accumulated in $\Delta$ sol5 mutants suggested that it is prosolanapyrone II with a vicinal diol on its hydrocarbon chain (Fig. 1A). The structural difference from prosolanapyrone II could have resulted from a high degree of substrate promiscuity of cytochrome P450 monooxygenase. Some P450 enzymes are prone to react with multiple substrates (Ekroos and Sjögren 2006; O'Reilly et al. 2013). Therefore, it is likely that the prosolanapyrone II that accumulated in $\Delta s o l 5$ mutants is oxidized by the physiologically irrelevant enzymatic reaction of a P450 (e.g., Sol6), forming an epoxide, which subsequently opens to form a vicinal diol. Notably, the sol6 gene was overexpressed in the $\Delta$ sol5 mutant (Fig. 2B). To the best of our knowledge, this is the first genetic evidence that Sol5 catalyzes both oxidation and Diels-Alder reaction in vivo.

Interestingly, soll and sol4 genes were overexpressed in the $\Delta$ sol5 mutant, suggesting that solanapyrone production is tightly controlled in the fungal cell. The accumulation of the precursor compound may lead to activation of the clustered genes, possibly via a positive feedback loop. However, identification of upstream genetic factors affecting solanapyrone production would be necessary for improved understanding of the regulation mechanism. The velvet protein complex is conserved across filamentous fungi and known to coordinate developmental processes and secondary metabolite production (Bok and Keller 2004; Wu et al. 2012). Given the association of solanapyrone production with the conidiation processes, the homologous velvet complex proteins in Ascochyta rabiei and Alternaria solani may be involved in the regulation of solanapyrone production, as shown in other polyketide-derived secondary metabolites such as T-toxin, aflatoxin, and lovastatin.

\section{Nonhost-selectivity of SolA.}

In our comparative toxicity assay of solanapyrones, we did not detect a difference in necrotic lesion size caused by SolA among chickpea accessions with different levels of resistance to the disease. This is in contrast to previous findings of positive correlations between susceptibility to Ascochyta blight and toxin sensitivity in chickpea accessions (Hamid and Strange 2000; Kaur 1995; Matern et al. 1978). Although only three accessions were tested in our study, we included the most resistant ('W6 22589', nearly immune to most of Ascochyta rabiei isolates) and the most susceptible (Spanish White, susceptible to both pathotypes I and II) (Chen et al. 2004).

In this study, we did not observe any specificity of solanapyrone toxins to specific legumes. Larger necrotic lesions were produced on nonhost legumes (pea, lentil, and sweet pea) than on chickpea. This may indicate a varying degree of sensitivity

A

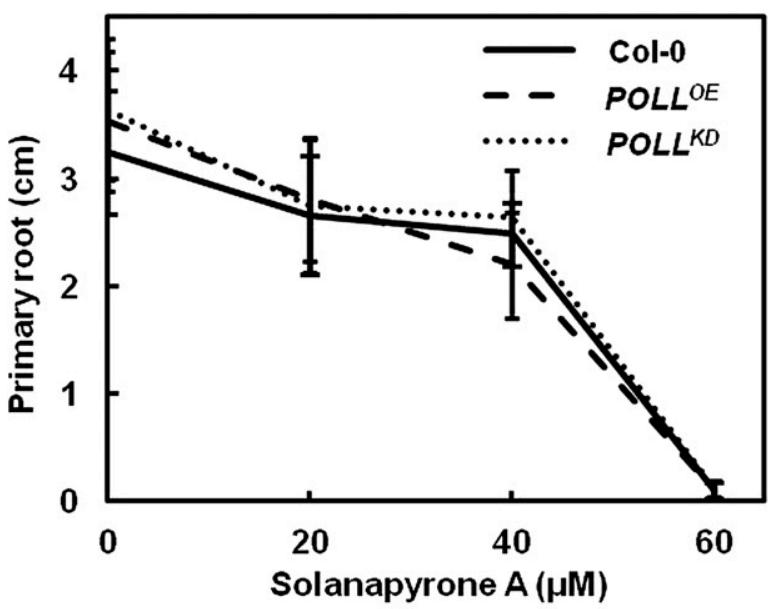

B

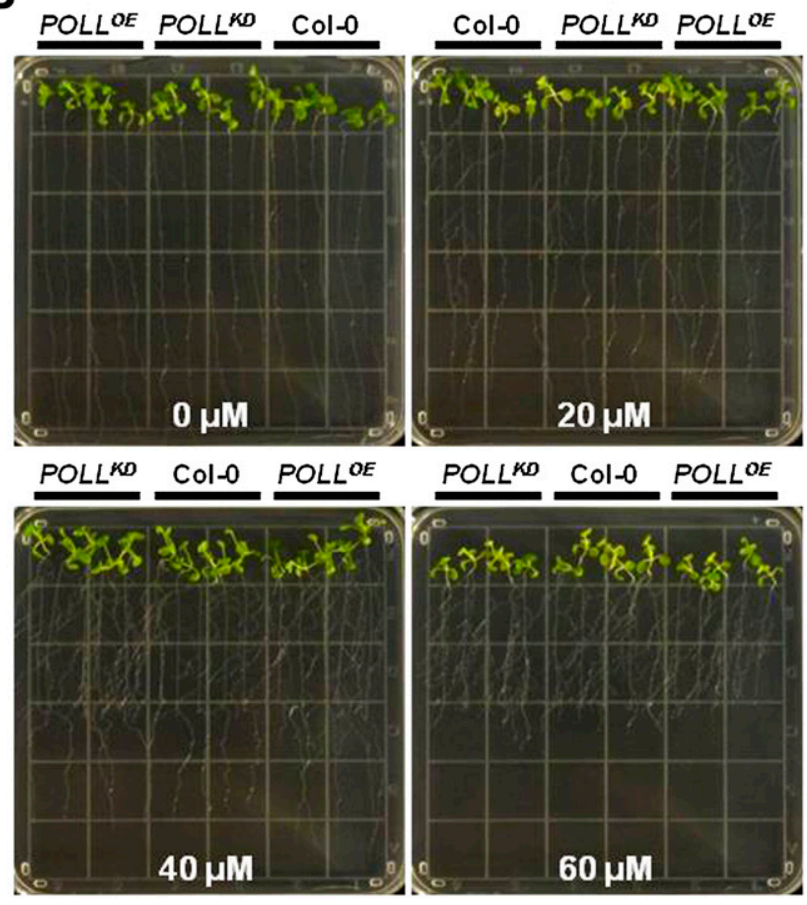

Fig. 6. Effects of solanapyrone A on root growth of Arabidopsis thaliana. A, Inhibition of primary root elongation by solanapyrone A. Primary root growth was measured 6 days after transfer of Arabidopsis seedlings (Col-0 ecotype, $P O L L^{O E}$, and $P O L L^{K D}$ ) to the half-strength Murashige and Skoog medium containing the indicated concentrations of solanapyrone A. Bars represent standard deviation $(n=17$ to 21$)$. B, Representative pictures showing lateral root branching induced by solanapyrone A. Pictures were taken 7 days after treatments. Note enhanced root branching by increasing concentrations of solanapyrone A. 
of plant species to SolA, as is the case for a phytotoxic compound produced by a closely related species, Ascochyta lentis (Andolfi et al. 2013). However, in our analysis, it was observed that the epidermis of the nonhost legumes was waxier than that of chickpea, and that droplets containing the test compounds remained for a longer period of times on the wounds. Due to the different texture of leaf surfaces, we were unable to test phytotoxicity on potato and tomato (the hosts of Alternaria solani). The droplets placed onto leaflets of potato or tomato spread out soon after application and, as a result, caused very small or no lesions. Therefore, the prolonged contact of test compounds on leaf wounds of the nonhost legumes may account for larger lesion size caused by SolA. Nevertheless, SolC and the precursor Pros-II-diol exhibited moderate or no effects on host and nonhost plants even at the highest concentration. These results suggest that SolA is a major nonhost-selective phytotoxin produced by Ascochyta rabiei and Alternaria solani.

\section{Effects of SolA on Arabidopsis thaliana.}

Many phytotoxic compounds target one or more cellular components, thereby disrupting normal cell function (Möbius and Hertweck 2009). SolA is also known to specifically bind to $\mathrm{X}$-family DNA polymerases in vitro (Mizushina et al. 2002). However, whether SolA exerts its toxic effect on plants by targeting the particular DNA polymerase is unknown. To shed light on the mode of action of SolA, we utilized the Arabidopsis model system. Upon SolA treatment, primary root growth of Arabidopsis was suppressed at a concentration of $60 \mu \mathrm{M}$. This substantial toxic effect of SolA on Arabidopsis is comparable with that of a well-known phytotoxin, deoxynivalenol (Masuda et al. 2007). However, Arabidopsis transgenic plants either lacking or overexpressing POLL gene responded to SolA similarly, indicating that POLL may not be the molecular target of SolA in Arabidopsis.

It is notable that SolA enhanced lateral root branching at concentrations at which the primary root was completely inhibited. This unique phenotype induced by SolA is reminiscent of primary root-specific inhibition caused by a synthetic compound used in a chemical genetics screen, which inhibits early abscisic acid signaling (Kim et al. 2012). Further genetic studies revealed that a member of nucleotide-binding site leucine-rich repeat (NB-LRR) proteins is responsible for the phenotype induced by the compound. This phenotypic similarity may suggest SolA functions in the signal transduction of the plant immune response in Arabidopsis. More recently, it was reported that victorin toxin produced by the necrotrophic fungus $C$. victoriae was known to activate the plant immune system through an NB-LRR protein (Lorang et al. 2012). For further studies, it will be of interest to search for a genetic factor contributing to the primary root arrest phenotype upon SolA treatment.

\section{Possible roles of solanapyrones in pathogen biology.}

Genomic loci implicated in pathogenicity and secondary metabolite production tend to be highly polymorphic and divergent; even within the same species (Cuomo et al. 2007; Rouxel et al. 2011). Among the worldwide collection of Ascochyta rabiei isolates, intraspecific karyotype variation was also observed (Akamatsu et al. 2012). Despite the high degree of genome plasticity of Ascochyta rabiei, sol5 gene was amplified from all 30 isolates chosen from the collection (Supplementary Table S2). Additionally, previous studies have detected production of solanapyrones in all the Ascochyta rabiei isolates used in the studies (Höhl et al. 1991; Kaur 1995). The universal production of solanapyrones and the highly conserved cluster genes between the two different fungal species, Ascochyta rabiei

Table 2. Mean lesion length and lesion number produced in chickpea cv. CDC Frontier stems inoculated with mixed inoculum of Ascochyta rabiei isolate AR628 (WT) and its $\Delta$ sol5 mutant

\begin{tabular}{lccc}
\hline Treatment & Lesion length $^{\mathbf{a}}$ & Lesion number & Total lesions $^{\mathbf{b}}$ \\
\hline Experiment 1 & & & \\
WT & 1.08 & 4.5 & 54 \\
$\Delta$ sol5 & 0.93 & 6.58 & 79 \\
$P$ value & 0.896 & 0.55 & 0.03 \\
Experiment 2 & & & \\
WT & 0.89 & 7.92 & 95 \\
$\Delta$ sol5 & 0.86 & 8.75 & 105 \\
$P$ value & 0.629 & 0.939 & 0.479 \\
\hline
\end{tabular}

${ }^{a}$ Length and number of lesions produced in one pot containing three chickpea plants were averaged out and considered an experimental unit $(n=12)$; lesion length in centimeters.

b Lesions produced in 12 pots were assigned either to WT or $\Delta$ sol5, based on colony morphology and selection marker resistance during subculture. ' $P$ values for lesion length and lesion number were obtained by Student's $t$ tests, and $P$ values for total lesion number were obtained by $\chi^{2}$ goodnessof-fit test.
A

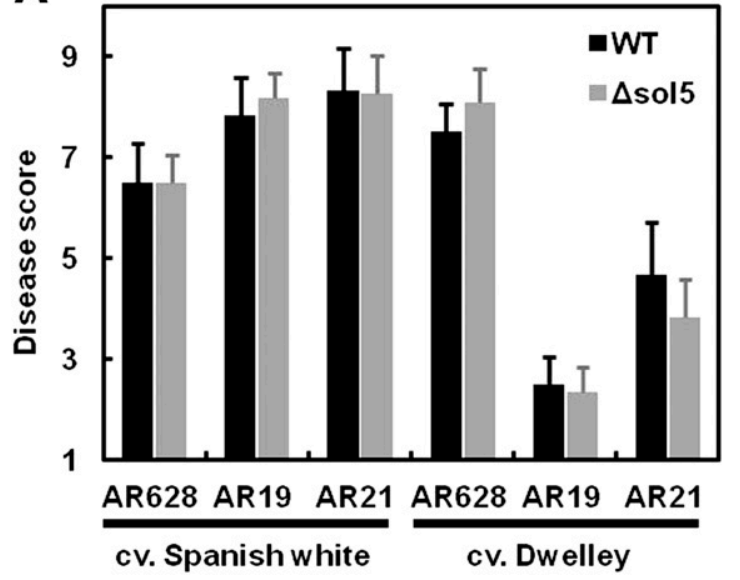

B

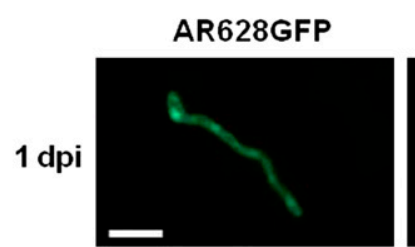
AR628GFPAsol5

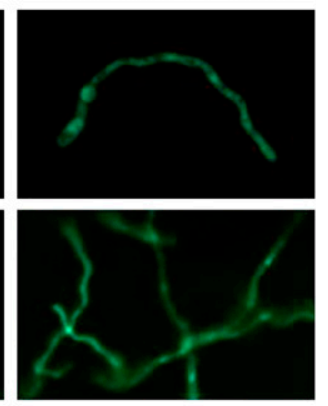

Fig. 7. Pathogenicity tests of Ascochyta rabiei and its $\Delta$ sol5 mutants. A, Mean disease severity of two chickpea cultivars (Spanish White and Dwelley) caused by three isolates-AR628 (pathotype II), AR19 (pathotype I), and AR21 (pathotype I) — and their corresponding $\Delta$ sol5 mutants. Disease score was assessed 2 weeks after inoculation based on the 1 -to- 9 rating scale $(1=$ no symptom and $9=$ dead plants). Student's $t$ test showed that the disease severity caused by the $\Delta$ sol5 mutants was not different from that caused by their respective wild-type (WT) progenitors. B, Visualization of germinating spores and subsequent hyphal branching of a green fluorescent-labeled strain (AR628GFP) and its $\Delta$ sol5 mutant version (AR628GFP $\Delta$ sol5) on leaflets of Spanish White. Bar $=20 \mu \mathrm{m}$. 
and Alternaria solani, suggests its indispensable role in pathogen biology other than parasitism.

Ascochyta rabiei undergoes the saprobic phase in its life cycle between chickpea growing seasons. The pathogen is able to survive in chickpea debris and remain viable for more than 2 years at a low relative humidity $(<30 \%)$ (Kaiser 1973). During this stage of the life cycle, the pathogen encounters numerous microbial competitors, including bacteria, fungi, and nematodes. In fact, many phytotoxins produced by phytopathogenic fungi display antibiotic activities (Ali-Vehmas et al. 1998; Boudart 1989; Waring et al. 1988). Also, it has been reported that solanapyrone analogs found in cultures of nonpathogenic fungi exhibited antibiotic activities (Schmidt et al. 2007; Trisuwan et al. 2009; Wu et al. 2009). Solanapyrones appear to be toxic to the fungi that produce them because the growth of the wild-type strains was restrained while solanapyrone-minus mutants were able to grow almost indeterminately (Fig. 3). The restricted growth of a maturing wild-type fungal colony may be a consequence of the antifungal activity of accumulated solanapyrones in culture. We are currently investigating possible ecological roles in niche specialization during saprobic growth of the pathogen life cycle such as competition with other microbes and survival on chickpea debris.

\section{MATERIALS AND METHODS}

Fungal strains and general culture conditions.

Ascochyta rabiei isolates AR19 (MAT1-2, ATCC 24891), AR21 (MAT1-1, ATCC 76502), and AR628 (MAT1-1, ATCC 201622) were obtained from the Ascochyta rabiei collection

Table 3. Lesion size $\left(\mathrm{cm}^{2}\right)$ caused by Alternaria solani isolates and $\Delta s o l 5$ mutants on leaves of potato and tomato cultivars

\begin{tabular}{lcccc}
\hline & \multicolumn{2}{c}{ Potato } & & Tomato \\
\cline { 2 - 3 } Strain & 'Russet Norkotah' & 'Ranger Russet' & & 'Moneymaker' \\
\hline ALS1WT & 0.87 & 0.59 & 1.06 \\
ALS1 'sol5 & 0.78 & 0.51 & 0.8 \\
ALS2WT & 0.77 & 0.47 & 1.15 \\
ALS2 & 0.65 & 0.41 & 0.82 \\
$P$ value & 0.919 & 0.403 & 0.611 \\
\hline
\end{tabular}

${ }^{a}$ Null hypothesis of no difference in mean lesion sizes produced by the wild-type and mutant strains was not rejected by one-way analysis of variance $(\alpha=0.05)$. maintained at the United States Department of Agriculture (USDA) Western Regional Plant Introduction Station. A green fluorescent protein-expressing strain of AR628 (Akamatsu et al. 2006) was also used for this study. Two field isolates (ALS1 and ALS2) of Alternaria solani, collected from separate fields in 2010 and 2011, were provided by Dr. Dennis Johnson (Washington State University, U.S.A.). Details on the isolates used in this study are listed in Table 1. For conidial production, Ascochyta rabiei isolates were grown on V8 agar media (200 $\mathrm{ml}$ of V8 juice, $3 \mathrm{~g}$ of $\mathrm{CaCO}_{3}$, and $20 \mathrm{~g}$ of agar in 1 liter of distilled water) for 2 weeks. For Alternaria solani isolates, spores were harvested from 2-week-old colonies on a modified PDA (1 g of potato dextrose agar [BD Diagnostic Systems, U.S.A.], $6 \mathrm{ml}$ of ethanol, and $20 \mathrm{~g}$ of agar in 1 liter of distilled water).

\section{Generation of gene replacement constructs and solanapyrone-minus mutants.}

The sol5 gene was specifically deleted from the genome of Ascochyta rabiei and Alternaria solani, using the split marker method (Catlett et al. 2003). DNA fragments of the gene replacement constructs overlapping within the hygromycin B phosphotransferase $(h p h)$ gene were amplified using a doublejoint PCR (Yu et al. 2004), with a minor modification. In the first round, PCR from genomic DNA of isolate AR628, an 800-bp region upstream of the sol5 coding region, was amplified using primer-1/primer-2 pair, and a 1,354-bp region downstream of the sol5 coding sequence was amplified using primer-3/primer-4 pair. A 1,372-bp hph cassette was amplified from pDWJ5 using HYG-F/HYG-R primer pair. Primer-2 and primer-3 carried 27-bp sequence tails that overlapped with the $5^{\prime}$ and $3^{\prime}$ ends, respectively, of the $h p h$ cassette. In the secondround PCR, each sol5-flanking DNA fragment was fused to the $h p h$ cassette through PCR by overlap extension. The resulting PCR products were cloned to pGEM-T Easy vector (Promega, U.S.A.). DNA sequences of the split-marker constructs were verified by sequencing with T7 or SP6 primer. The vectors cloned with the upstream flanking DNA construct and the downstream flanking DNA construct were used as templates for the third-round PCR with nested primer pairs: primer-7/HY-R pair for the upstream flanking DNA construct and primer-8/ YG-F pair for the downstream flanking DNA construct. The upstream and downstream split-marker constructs were used for transformation of both Ascochyta rabiei and Alternaria
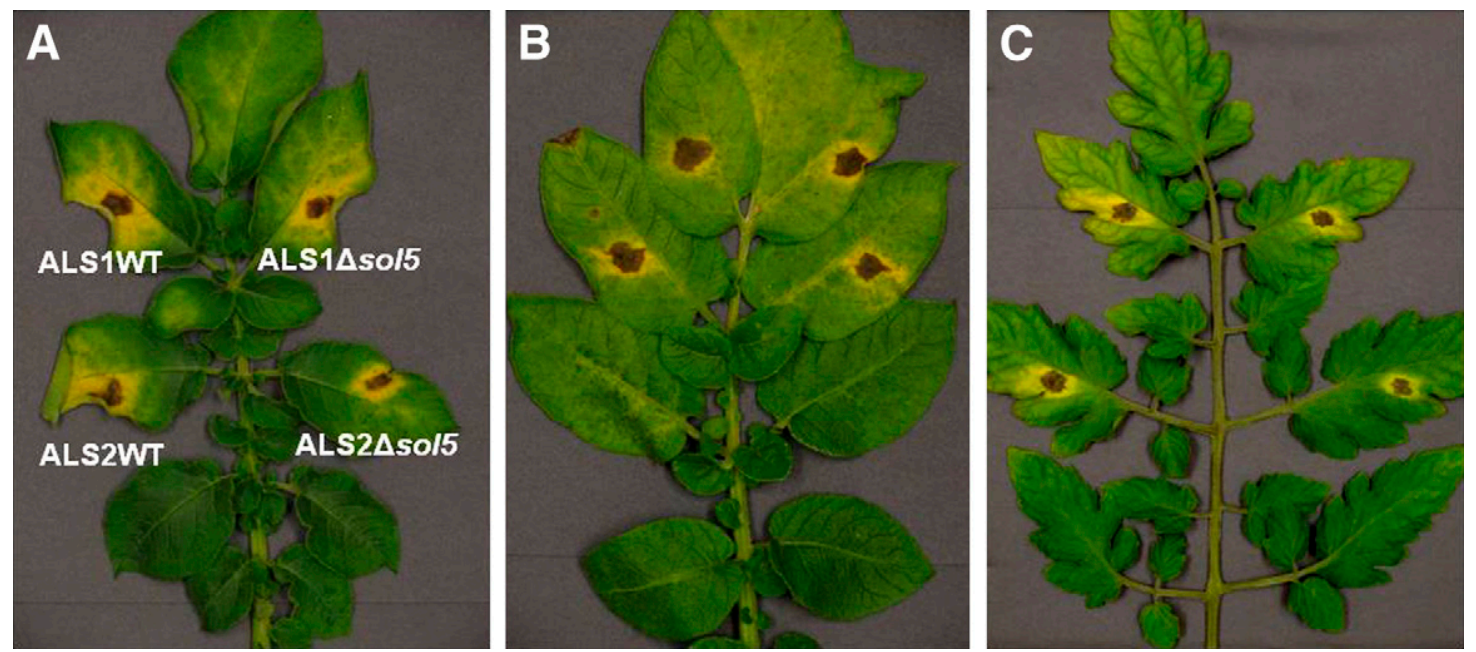

Fig. 8. Detached leaf assay for virulence of Alternaria solani isolates (ALS1 and ALS2) and the corresponding $\Delta$ sol5 mutants on potato A, 'Russet Norkotah' and B, 'Ranger Russet', and C, tomato 'Moneymaker'. Arrangement of strains is as in A. 
solani. Primers and their sequences used in this study are listed in Supplementary Table S1.

\section{Fungal transformation and molecular confirmation of transformants.}

Preparation of fungal protoplasts and transformation were conducted as previously described, with a minor modification (Akamatsu et al. 2010). Instead of using a disruption plasmid vector, 1 to $5 \mu \mathrm{g}$ of each upstream and downstream splitmarker DNA construct were used for genetic transformation of Ascochyta rabiei and Alternaria solani. Putative transformants were subcultured on V8 agar containing hygromycin B (200 $\mu \mathrm{g} / \mathrm{ml})$, and two rounds of single-spore isolation were conducted to obtain homokaryotic transformants. Selected transformants were screened by a diagnostic PCR with the primer-11/primer-12 pair to amplify the full-length DNA sequence of gene sol5 in wild types and the $h p h$ cassette in putative $\Delta$ sols mutants. Homologous integration of the split-marker DNA constructs were verified by PCR with an upstream flanking primer, primer-1, and HYG-R, confirming correct integration of the split-marker constructs into the sol5 gene locus.

\section{Growth rate and in vitro sexual stage induction.}

Agar plugs ( $3 \mathrm{~mm}$ in diameter) containing actively growing mycelia on PDA were transferred to fresh PDA and the cultures were incubated under $12 \mathrm{~h}$ of fluorescent light at $20 \pm 2{ }^{\circ} \mathrm{C}$. Colony diameters in orthogonal directions in five replicate plates (13.5 cm in diameter) for each strain were measured in 3-day intervals for up to 36 days.

Isolates AR628 (MAT1-1) and AR19 (MAT1-2) or their corresponding $\Delta$ sol5 mutants were crossed as previously described by Wilson and Kaiser (1995). Production of pseudothecia and ascospores on chickpea straw was examined 8 weeks after incubation at $10^{\circ} \mathrm{C}$.

\section{RNA extraction, RT-PCR, and quantitative real-time RT-PCR analyses.}

RNA was extracted from cultures (mycelia and spores) of isolate AR628 and its $\Delta$ sol5 mutant using the RNeasy Plant Mini Kit (Qiagen). On-column digestion of possible genomic DNA contamination was performed using RNase-Free DNase Set (Qiagen). For RT-PCR analysis of solanapyrone biosynthesis genes, $200 \mathrm{ng}$ of RNAs were reverse transcribed and amplified using the OneStep RT-PCR kit (Qiagen). The sol genes (soll to sol6) were amplified for 30 to 32 cycles and actinl for 28 cycles (annealing temperature $=62^{\circ} \mathrm{C}$ ). The primer sets for RT-PCR analysis were designed to amplify flanking exons, including one intron in order to distinguish mRNA from premRNA (or possible gDNA contamination). Real-time RT-PCR assays were used to monitor expression levels of solland sol5 genes. Isolate AR628 was grown on PDA and sampled for RNA extraction at 3-day intervals up to 21 days. For comparison of sol gene expression on PDA between the wild type and the $\Delta$ sol 5 mutant, RNA was extracted from PDA culture 9 days after inoculation. First-strand cDNA synthesis was prepared from total RNA using the iScript cDNA Synthesis Kit (Bio-Rad) according to the manufacturer's instructions. Real-time RT-PCR analyses were performed using the BioRad iQ5 Real-Time PCR Detection System. RT-PCR mixtures were composed of 12 pmol of each primer, $12.5 \mu \mathrm{l}$ of SYBR Green Supermix (Bio-Rad), $2 \mu$ of cDNA (a 1:2.5 dilution of the $20-\mu l$ cDNA product), and nuclease-free water to a final volume of $25 \mu \mathrm{l}$. The PCR conditions consisted of a denaturing step at $95^{\circ} \mathrm{C}$ for $2 \mathrm{~min}$, a DNA denaturation step at $95^{\circ} \mathrm{C}$ for $10 \mathrm{~s}$, both annealing and extension steps at $62^{\circ} \mathrm{C}$ for $30 \mathrm{~s}$ for 45 cycles, and 65 to $95^{\circ} \mathrm{C}$ with a $0.5^{\circ} \mathrm{C}$ increment and each temperature for $5 \mathrm{~s}$ to obtain the melting curve. The quantification of the relative transcript levels of the solanapyrone biosynthesis genes in Ascochyta rabiei was performed with the comparative cycle threshold method normalization (Schmittgen and Livak 2008). The transcript levels of target genes were normalized against the actin1 gene transcript levels. The averages of the three biological replicates and standard deviations of the relative expression values were presented. Primers used in this study and their sequences are listed in Supplementary Table S1.

\section{Solanapyrone extraction and purification.}

For extraction of solanapyrones from liquid cultures of Ascochyta rabiei and Alternaria solani isolates, $30 \mathrm{ml}$ of halfstrength potato dextrose broth (PDB) in 250-ml Erlenmeyer flasks was inoculated with $100 \mu \mathrm{l}$ of a conidial suspension of Ascochyta rabiei isolates $\left(1 \times 10^{7}\right.$ spores $\left.\mathrm{ml}^{-1}\right)$, or Alternaria solani isolates $\left(1 \times 10^{5}\right.$ spores $\left.\mathrm{ml}^{-1}\right)$, and incubated at $20^{\circ} \mathrm{C}$ without shaking. After 16 to 18 days, cultures were filtered through four layers of Miracloth (Calbiochem, U.S.A.) in a vacuum to remove mycelium. Solanapyrones were extracted using Sep-Pak Vac 6- $\mathrm{cm}^{3}$ (1-g) tC18 cartridges (Waters Corp., Milford, MA, U.S.A.). Individual cartridges were eluted with $2 \mathrm{ml}$ of $\mathrm{MeOH}$ and the eluents were subjected to UPLC-MS analysis.

For purification of SolA and SolC, $200 \mathrm{~g}$ of autoclaved oat kernels in a mason jar (approximately 1-liter size) were inoculated with approximately 50 agar plugs ( $5 \mathrm{~mm}$ in diameter) containing actively growing mycelia of isolate AR628 or the $\Delta$ sol5 mutant on V8 agar. The culture was incubated at $20^{\circ} \mathrm{C}$ under a regime of $12 \mathrm{~h}$ of light and $12 \mathrm{~h}$ of darkness and shaken daily to disperse the inocula. After 16 days, solanapyrones were extracted from the Ascochyta rabiei-colonized oat kernels with $200 \mathrm{ml}$ of ethyl acetate (EtOAc). Extracts were dried over anhydrous $\mathrm{MgSO}_{4}$ and filtered through four layers of cheesecloth to remove oat kernel debris and $\mathrm{MgSO}_{4}$ and concentrated on a rotary evaporator. The residue was further purified by preparative TLC on silica gel: SolA $\left(R_{f} 0.58\right.$, eluent $\mathrm{CHCl}_{3} / \mathrm{EtOH}$ [95:5, vol/vol], yielding $2.8 \mathrm{mg})$ and SolC $\left(R_{f} 0.44\right.$, eluent $\left.\mathrm{CHCl}_{3} / \mathrm{EtOH}[95: 5, \mathrm{vol} / \mathrm{vol}], 1.3 \mathrm{mg}\right)$. Analytical and preparative TLC were performed on TLC LuxPlate Silica gel 60 $\mathrm{F}_{254}$ plates $(0.25$ and $1.0 \mathrm{~mm})$ (Merck, Germany). The spots were visualized by exposure to UV radiation $(254 \mathrm{~nm})$. For purification, UV-active spots of individual compounds on silica gel were collected separately and dissolved in EtOAc/MeOH (9:1, vol/vol) to elute target compounds out from the silica gel.

For purification of the major compound eluted at $2.26 \mathrm{~min}$ in the chromatograms of the $\Delta$ sol 5 mutants, culture filtrates of AR628 $\Delta$ sol5 grown in half-strength PDB were partitioned with the same volume of EtOAc, and the organic phases were combined and partitioned again with distilled water ( $\mathrm{pH} 3.0)$. Finally, the organic phases were combined and dried over anhydrous $\mathrm{MgSO}_{4}$ and concentrated on a rotary evaporator. The residue was purified by preparative TLC on silica gel-ProsII-diol $\left(R_{f} 0.26\right.$, eluent EtOAc/ $\mathrm{MeOH} / \mathrm{H}_{2} \mathrm{O}$ [80:5:5, vol/vol], $4.1 \mathrm{mg}$ ) - and subjected to spectrometric analyses for structural identification.

\section{Spectrometric data for structural identification of Pros-II-diol.}

${ }^{1} \mathrm{H}$ NMR $\left(300 \mathrm{MHz}, \mathrm{CDCl}_{3}+\mathrm{D}_{2} \mathrm{O}\right) \delta 6.77(\mathrm{dt}, J=14.7,7.1$ $\mathrm{Hz}, 1 \mathrm{H}), 6.12-5.90(\mathrm{~m}, 2 \mathrm{H}), 5.73$ (ddd, $J=15.1,7.0,6.0 \mathrm{~Hz}$, $1 \mathrm{H}), 5.59-5.44(\mathrm{~m}, 1 \mathrm{H}), 4.54(\mathrm{~s}, 2 \mathrm{H}), 4.01(\mathrm{dd}, J=7.1,3.6 \mathrm{~Hz}$, $1 \mathrm{H}), 3.90(\mathrm{~s}, 3 \mathrm{H}), 3.85(\mathrm{dd}, J=6.4,3.7 \mathrm{~Hz}, 1 \mathrm{H}), 2.29-2.18(\mathrm{~m}$, $2 \mathrm{H}), 2.15-2.02(\mathrm{~m}, 2 \mathrm{H}), 1.54-1.36(\mathrm{~m}, 2 \mathrm{H}), 1.13(\mathrm{~d}, J=6.3$ $\mathrm{Hz}, 3 \mathrm{H}) ;{ }^{13} \mathrm{C} \mathrm{NMR}\left(75 \mathrm{MHz}, \mathrm{CDCl}_{3}+\mathrm{D}_{2} \mathrm{O}\right) \delta 167.14,164.99$, 159.76, 141.40, 134.91, 128.21, 121.89, 104.98, 94.49, 76.77, $70.14,56.45,54.83,32.84,32.33,28.72,28.12,17.91$; IR (thin film) 
$3407.5,3011.1,2933.5,2851.8,1679.0,1548.2,1458.4,1266.3$, $1004.8,747.3 \mathrm{~cm}^{-1}$; ESI $\mathrm{m} / z$, calculated for $\mathrm{C}_{18} \mathrm{H}_{26} \mathrm{NaO}_{6}[\mathrm{M}+\mathrm{Na}]^{+}$ 361.2, observed 361.1.

\section{UPLC-MS analysis.}

Chromatographic separation was achieved using an ACQUITY UPLC system (Waters Corp.) on a 2.1-by-50-mm i.d., 1.7- $\mu \mathrm{m}$, ACQUITY UPLC BEH C18 column (Waters Corp.). Mobile phase A was water with $0.1 \%$ formic acid, and mobile phase B was acetonitrile with $0.1 \%$ formic acid. The gradient started from $7 \% \mathrm{~B}$, followed by an 8-min linear gradient from 7 to $99 \% \mathrm{~B}$. The gradient was held for 2 min and was finally stepped to $7 \%$ B to equilibrate the column for $2 \mathrm{~min}$. The total $\mathrm{LC}$ run time was $13 \mathrm{~min}$, the column temperature was maintained at $30^{\circ} \mathrm{C}$, and the flow rate was $0.45 \mathrm{ml} \mathrm{min}^{-1}$.

MS analysis was performed on an inline Synapt G2-S HDMS (Waters Corp.) time-of-flight (TOF) mass spectrometer. Positive ion electrospray mode was used for data collection. The desolvation gas was nitrogen $\left(800\right.$ liters $\left.\mathrm{h}^{-1}\right)$, and the collision gas was argon $\left(2.0 \mathrm{ml} \mathrm{min}^{-1}\right)$. The data acquisition range was $\mathrm{m} / \mathrm{z}, 50$ to 1,000 . The source temperature was $120^{\circ} \mathrm{C}$ and the desolvation temperature was $250^{\circ} \mathrm{C}$. The cone voltage was $30 \mathrm{~V}$. The lock mass compound used was leucine encephalin with a reference mass at $\mathrm{m} / \mathrm{z} 556.2771$.

For the TOF experiments, data were acquired in the $\mathrm{MS}^{\mathrm{E}}$ mode, in which two separate scan functions were programmed for the MS acquisition method. One scan function was set at low collision energy (trap at $4 \mathrm{eV}$ and transfer at $2 \mathrm{eV}$ ), and the other scan function was set at high collision energy (trap ramped from 15 to $50 \mathrm{eV}$ and transfer at $2 \mathrm{eV}$ ). The mass spectrometer switched rapidly between the two functions during data acquisition. As a result, information on intact precursor ions and on product ions was obtained from a single LC run.

For identification of the peak eluted at 4.32 in the chromatograms of the wild-type culture extracts, the following methodology was used. First, the elemental composition of the detected peak was determined by comparing the exact mass of the precursor ion detected in the low-collision energy spectrum and the exact mass of the proposed candidate (only differences below $5 \mathrm{mDa}$ were accepted). A good fit in the isotopic pattern of both compounds was also required for the selection of the best candidate. The suitability of possible oxidized forms of SolA was checked through MassFragment software (Waters Corp.). MassFragment made it possible to evaluate whether the product ions detected in the high-collision energy spectrum were linked to the fragments generated from the chemical structures of the candidates proposed. A score between 1 and 14 was provided by the software for each product ion. The lower the score value, the higher the plausibility of the fragment proposed. An oxidized form of SolA was considered confirmed by MassFragment software because most of the product ions showed that the score provided by the software was equal to or below 3 .

\section{Phytotoxicity tests.}

The phytotoxicity of SolA, SolC, and Pros-II-diol was tested on chickpea genotypes W6 22589 (resistant), 'FLIP 84-92C' (intermediate), and Spanish White (susceptible); pea 'Dark Skin Perfection' (Pisum sativum), lentil 'Pardina' (Lens culinaris), and sweet pea 'Spencer'-type mix (Lathyrus odoratus). Three plants of each species were grown in 1-liter plastic pots filled with Sunshine mix number 4 (Sun Gro Horticulture, Canada) and maintained for 4 weeks in a growth chamber (Conviron Model PGR15, Winnipeg, Manitoba, Canada) at $12 \mathrm{~h} /$ day $\left(20^{\circ} \mathrm{C}\right)$ and $12 \mathrm{~h} /$ night $\left(16^{\circ} \mathrm{C}\right)$. The youngest, fully expanded leaves (leaves of the second or the third nodes from the top) were detached from each plant, and the adaxial sides of leaflets were gently punctured with a pin to facilitate absorption of test compounds. The leaflets were placed on two layers of plastic mesh in a glass tray $(22$ by $30 \mathrm{~cm})$ with wet paper towels, and the trays were covered with a plastic bag to keep leaflets moist and kept at $20^{\circ} \mathrm{C}$. Purified compounds were adjusted to $16.5 \mu \mathrm{g} / \mu \mathrm{l}$ by adding $\mathrm{MeOH}$ and then brought up to a final concentration of $1 \mu \mathrm{g} / \mu \mathrm{l}$ in distilled water. A drop $(3 \mu \mathrm{l})$ of each solution or solvent control $(6 \% \mathrm{MeOH})$ was placed onto the punctured wound on the epidermis ( 9 to 12 leaflets per treatment). Necrotic lesions were photographed 3 days after application. The areas of necrotic lesions were calculated using Assess 2.0 Image Analysis Software for Plant Disease Quantification (APS Press, U.S.A.) and used as an indicator of phytotoxicity.

Arabidopsis thaliana seed, $P O L L$-overexpressing transgenic line $\left(P O L L^{O E}\right)$, and T-DNA insertion line (SALK 075391, $P O L L^{K D}$ ) were obtained from Drs. Rino Cella and Giovanni Maga (University of Pavia, Italy). The overexpression and knockdown of the POLL gene were verified via real-time RTPCR analysis using the method described by Amoroso and associates (2011) (Supplementary Fig. S7). Surface-sterilized Arabidopsis seed were sown on half strength Murashige and Skoog growth media (pH 5.7) supplemented with $1.0 \%$ sucrose and $0.7 \%$ phytoagar in square plastic petri dishes with grids (BD Biosciences, U.S.A.). After 3 days of vernalization, the plates were kept in a growth chamber (cycle of 16 and $8 \mathrm{~h}$ of light and darkness, respectively, at $22^{\circ} \mathrm{C}$ ) for 7 days. The seedlings were gently transferred to Murashige and Skoog growth media containing different concentrations of SolA $(20,40$, or $60 \mu \mathrm{M})$. The plates were further incubated for 6 days and growth of primary roots was measured and photographed. For media without SolA $(0 \mu \mathrm{M}), \mathrm{MeOH}$ was amended to the Murashige and Skoog growth media as a solvent control $(0.5 \%, \mathrm{vol} / \mathrm{vol})$.

\section{Pathogenicity assays.}

Pathogenicity tests (using Spanish White and Dwelley chickpea) and disease assessment were conducted as described by Chen and associates (2004). For a coinoculation experiment, three seeds of CDC Frontier chickpea were sown in 1-liter plastic pot (12 pots for the experiment) containing Sunshine mix number 4 (Sun Gro Horticulture) and maintained in a growth chamber (Conviron Model PGR15) under a 12-h photoperiod of $20^{\circ} \mathrm{C}$ (day) and $16^{\circ} \mathrm{C}$ (night) at $>95 \%$ relative humidity. Spores of the wild-type strain (AR628WT) and its $\Delta$ sol5 mutant (AR628 $\Delta$ sol5) were harvested from $\mathrm{V} 8$ agar media and mixed at a $1: 1$ ratio in sterilized water, making a final concentration of $2 \times 10^{5}$ spores $\mathrm{ml}^{-1}$. The inoculation method was as described by Chen and associates (2004). In order to calculate relative infection rates of AR628WT and AR628 $\Delta$ sol5, the total number of lesions produced after incubation for 2 weeks was counted and each lesion was numbered and cut from the plant along with a stem segment (approximately $3 \mathrm{~cm}$ long). After measuring lesion length, the fungal genotype that caused the lesion was isolated and determined by assessing colony morphology on acidified PDA (39 $\mathrm{g}$ of PDA and $1 \mathrm{ml}$ of lactic acid per liter added after autoclaving, $\mathrm{pH} 3.5$ ); fungal colonies exhibiting a dark and restricted growth pattern were assigned to AR628WT, while lighter colonies with expansive growth were assigned to AR628 $\Delta$ sol5. The identity of each fungal colony was further confirmed by subculturing on V8 agar containing hygromycin B at $200 \mu \mathrm{g} / \mathrm{ml}$; AR628 $\Delta$ sol5 can grow on medium containing hygromycin B, whereas AR628WT cannot. Lesions from which both AR628WT and AR628 $\Delta$ sol5 were obtained (less than $10 \%$ of total lesions) were not included in the $\chi^{2}$ goodness-offit test.

A detached-leaf assay was used for measuring virulence of Alternaria solani isolates ALS1 and ALS2 and their respective 
$\Delta$ sol5 mutants. Leaves were excised from 6-week-old plants of two potato cultivars ('Russet Norkotah' and 'Ranger Russet') and one tomato cultivar ('Moneymaker') grown in a greenhouse under a 16 -h photoperiod at $25^{\circ} \mathrm{C}$ (day) and $18^{\circ} \mathrm{C}$ (night). Detached leaves were inoculated with $10 \mu \mathrm{l}$ of spore suspension $\left(2 \times 10^{4}\right.$ spores $\left.\mathrm{ml}^{-1}\right)$ contained in a lens paper $(0.7 \mathrm{~cm}$ in diameter). Leaves were placed on a glass tray with five layers of paper towels at room temperature, and covered with a transparent plastic bag to maintain near $100 \%$ relative humidity. The inoculated leaves were photographed at $6 \mathrm{dpi}$. The area of the necrotic lesion on each leaf was calculated by the analysis of images as described above. The lesion areas were calibrated based on area of a square $\left(1 \mathrm{~cm}^{2}\right)$ paper that was included in each photograph.

\section{Data analyses.}

For pathogenicity tests with Spanish White and Dwelley chickpea, experiments were conducted in completely randomized designs. Disease severity ratings ( 1 to 9 ) were recorded for each plant and the mean of the two plants in a pot represented one experimental unit $(n=6)$. Levene's test for equal variance assumption was used to determine whether variance was independent of the mean and Shapiro-Wilk test was used to check for normality assumption. Student's $t$ test was used for mean comparisons between the wild-type strain and its corresponding $\Delta$ sol5 mutant. For the coinoculation experiment, the $\chi^{2}$ goodness-of-fit test was used to detect any deviation from the expected 1:1 ratio in total number of stem lesions caused by the wild type (AR628WT) and $\Delta$ sol5 mutant (AR628 $\Delta$ sol5). The mean lesion length and lesion number caused by AR628 $\Delta$ sol5 were compared with those caused by AR628WT, using Student's $t$ test. Mean lesion length and lesion number produced on three chickpea plants (CDC Frontier) in a pot represented one experimental unit $(n=12)$.

For the detached-leaf assay, differences in average lesion size produced on potato or tomato leaves by each strain were analyzed using one-way analysis of variance (ANOVA) (main effect, strain). No significant difference in mean lesion size was observed at a significance level of 0.05 . Lesions produced on each detached leaf represented one experimental unit $(n=8)$. For the phytotoxicity test, square-root transformed data were used for one-way ANOVA (main effect, legume species) because the original data violated the normality and equal variance assumptions. After data transformation, the assumptions were checked by Shapiro-Wilk's and maximum likelihood ratio tests. Multiple comparisons of mean lesion size incited by application of $3 \mu \mathrm{g}$ of SolA between different legume species were performed by a least significant difference test using Bonferroni correction. Null hypotheses of no difference were rejected when $P \leq 0.05$. Lesions produced on excised leaflets represented one experimental unit ( $n=10$ to 12$)$. The analyses were performed using the MIXED procedure in SAS software (v9.2; SAS Institute Inc., U.S.A.).

\section{ACKNOWLEDGMENTS}

We thank R. Cella and G. Maga (University of Pavia, Italy) for kindly providing Arabidopsis transgenic lines (POLL ${ }^{O E}$ and $\left.P O L L^{K D}\right)$, A. Vanden Wymelenberg (University of Wisconsin) and D. Cullen (USDA Forest Service) for providing pTEFEGFP, H. Oikawa (Hokkaido University) for providing solanapyrone A standard, and H. J. Kim (Korea University) for valuable suggestions on solanapyrone biochemistry. The research was funded, in part, by the USDA Cool Season Food Legume Research Program and by the USA Dry Pea and Lentil Council. Mass spectrometric analysis was performed on an instrument acquired through a Major Research Instrumentation grant (DBI-1229749) from the National Science Foundation to D. R. Gang.

\section{LITERATURE CITED}

Akagi, Y., Akamatsu, H., Otani, H., and Kodama, M. 2009. Horizontal chromosome transfer, a mechanism for the evolution and differentiation of a plant-pathogenic fungus. Eukaryot. Cell 8:1732-1738.

Akamatsu, H. O., Stone, L. J., Sigler, A. A., Chilvers, M. I., Arie, T., and Peever, T. L. 2006. Heterologous expression of fluorescence protein in the phytopathogenic fungus Ascochyta rabiei and visualization of the fungus in planta. (Abstr.) Phytopathology 96:S4.

Akamatsu, H. O., Chilvers, M. I., Stewart, J. E., and Peever, T. L. 2010 Identification and function of a polyketide synthase gene responsible for 1,8-dihydroxynaphthalene-melanin pigment biosynthesis in Ascochyta rabiei. Curr. Genet. 56:349-360.

Akamatsu, H. O., Chilvers, M. I., Kaiser, W. J., and Peever, T. L. 2012. Karyotype polymorphism and chromosomal rearrangement in populations of the phytopathogenic fungus, Ascochyta rabiei. Fungal Biol. 116: 1119-1133.

Alam, S. S., Bilton, J. N., Slawin, A. M. Z., Williams, D. J., Sheppard, R. N., and Strange, R. N. 1989. Chickpea blight: Production of the phytotoxins solanapyrones $\mathrm{A}$ and $\mathrm{C}$ by Ascochyta rabiei. Phytochemistry 28:2627-2630.

Ali-Vehmas, T., Rizzo, A., Westermarck, T., and Atroshi, F. 1998. Measurement of antibacterial activities of T-2 toxin, deoxynivalenol, ochratoxin A, aflatoxin B1 and fumonisin B1 using microtitration traybased turbidimetric techniques. J. Vet. Med. Ser. A 45:453-458.

Amoroso, A., Concia, L., Maggio, C., Raynaud, C., Bergounioux, C., Crespan, E., Cella, R., and Maga, G. 2011. Oxidative DNA damage bypass in Arabidopsis thaliana requires DNA polymerase $\lambda$ and proliferating cell nuclear antigen 2. Plant Cell 23:806-822.

Andolfi, A., Cimmino, A., Villegas-Fernández, A. M., Tuzi, A., Santini, A., Melck, D., Rubiales, D., and Evidente, A. 2013. Lentisone, a new phytotoxic anthraquinone produced by Ascochyta lentis, the causal agent of Ascochyta blight in Lens culinaris. J. Agric. Food Chem. 61: 7301-7308.

Auclair, K., Sutherland, A., Kennedy, J., Witter, D. J., Van den Heever, J. P., Hutchinson, C. R., and Vederas, J. C. 2000. Lovastatin nonaketide synthase catalyzes an intramolecular Diels-Alder reaction of a substrate analogue. J. Am. Chem. Soc. 122:11519-11520.

Bahti, P., and Strange, R. N. 2004. Chemical and biochemical reactions of solanapyrone A, a toxin from the chickpea pathogen, Ascochyta rabiei (Pass.). Labr. Physiol. Mol. Plant Pathol. 64:9-15.

Barve, M. P., Arie, T., Salimath, S. S., Muehlbauer, F. J., and Peever, T. L. 2003. Cloning and characterization of the mating type (MAT) locus from Ascochyta rabiei (teleomorph: Didymella rabiei) and a MAT phylogeny of legume-associated Ascochyta spp. Fungal Genet. Biol. 39:151-167.

Bok, J. W., and Keller, N. P. 2004. LaeA, a regulator of secondary metabolism in Aspergillus spp. Eukaryot. Cell 3:527-535.

Boudart, G. 1989. Antibacterial activity of sirodesmin PL phytotoxin: Application to the selection of phytotoxin-deficient mutants. Appl Environ. Microbiol. 55:1555-1559.

Catlett, N. L., Lee, B. N., Yoder, O. C., and Turgeon, B. G. 2003. Splitmarker recombination for efficient targeted deletion of fungal genes. Fungal Genet. Newsl. 50:9-11.

Chen, Y. M., and Strange, R. N. 1991. Synthesis of the solanapyrone phytotoxins by Ascochyta rabiei in response to metal cations and development of a defined medium for toxin production. Plant Pathol. 40: 401-407.

Chen, W., Coyne, C. J., Peever, T. L., and Muehlbauer, F. J. 2004 Characterization of chickpea differentials for pathogenicity assay of Ascochyta blight and identification of chickpea accessions resistant to Didymella rabiei. Plant Pathol. 53:759-769.

Cuomo, C. A., Güldener, U., Xu, J.-R., Trail, F., Turgeon, B. G., Di Pietro, A., Walton, J. D., Ma, L.-J., Baker, S. E., Rep, M., Adam, G., Antoniw, J., Baldwin, T., Calvo, S., Chang, Y.-L., Decaprio, D., Gale, L. R., Gnerre, S., Goswami, R. S., Hammond-Kosack, K., Harris, L. J., Hilburn, K., Kennell, J. C., Kroken, S., Magnuson, J. K., Mannhaupt, G., Mauceli, E., Mewes, H.-W., Mitterbauer, R., Muehlbauer, G., Münsterkötter, M., Nelson, D., O'donnell, K., Ouellet, T., Qi, W., Quesneville, H., Roncero, M. I. G., Seong, K.-Y., Tetko, I. V., Urban, M., Waalwijk, C., Ward, T. J., Yao, J., Birren, B. W., and Kistler, H. C. 2007. The Fusarium graminearum genome reveals a link between localized polymorphism and pathogen specialization. Science 317:1400-1402.

Doolittle, W. F. 1999. Lateral genomics. Trends Cell Biol. 9:M5-M8.

Durrant, W. E., Wang, S., and Dong, X. 2007. Arabidopsis SNI1 and RAD51D regulate both gene transcription and DNA recombination during the defense response. Proc. Natl. Acad. Sci. U.S.A. 104 4223-4227. 
Ekroos, M., and Sjögren, T. 2006. Structural basis for ligand promiscuity in cytochrome P450 3A4. Proc. Natl. Acad. Sci. U.S.A. 103 13682-13687.

García-Díaz, M., Domínguez, O., López-Fernández, L. A., de Lera, L. T., Saníger, M. L., Ruiz, J. F., Párraga, M., García-Ortiz, M. J., Kirchhoff, T., del Mazo, J., Bernad, A., and Blanco, L. 2000. DNA polymerase lambda (Pol lambda), a novel eukaryotic DNA polymerase with a potential role in meiosis. J. Mol. Biol. 301:851-867.

Grigoriev, I. V., Nikitin, R., Haridas, S., Kuo, A., Ohm, R., Otillar, R., Riley, R., Salamov, A., Zhao, X., Korzeniewski, F., Smirnova, T., Nordberg, H., Dubchak, I., and Shabalov, I. 2014. MycoCosm portal: Gearing up for 1000 fungal genomes. Nucleic Acids Res. 42, Database issue: D699-D704.

Hamid, K., and Strange, R. N. 2000. Phytotoxicity of solanapyrones A and B produced by the chickpea pathogen Ascochyta rabiei (Pass.) Labr. and the apparent metabolism of solanapyrone A by chickpea tissues. Physiol. Mol. Plant Pathol. 56:235-244.

Höhl, B., Weidemann, C., Höhl, U., and Barz, W. 1991. Isolation of solanapyrones $\mathrm{A}, \mathrm{B}$ and $\mathrm{C}$ from culture filtrates and spore germination fluids of Ascochyta rabiei and aspects of phytotoxin action. J. Phytopathol. 132:193-206.

Ichihara, A., Tazaki, H., and Sakamura, S. 1983. Solanapyrones A, B and C, phytotoxic metabolites from the fungus Alternaria solani. Tetrahedron Lett. 24:5373-5376.

Inderbitzin, P., Asvarak, T., and Turgeon, B. G. 2010. Six new genes required for production of T-toxin, a polyketide determinant of high virulence of Cochliobolus heterostrophus to maize. Mol. Plant-Microbe Interact. 23:458-472.

Iruela, M., Rubio, J., Barro, F., Cubero, J. I., Millán, T., and Gil, J. 2006. Detection of two quantitative trait loci for resistance to Ascochyta blight in an intra-specific cross of chickpea (Cicer arietinum L.): Development of SCAR markers associated with resistance. Theor. Appl. Genet. 112: 278-287.

Jayakumar, P., Gan, Y. T., Gossen, B. D., Warkentin, T. D., and Banniza, S. 2005. Ascochyta blight of chickpea: Infection and host resistance mechanisms. Can. J. Plant Pathol. 27:499-509.

Kaiser, W. J. 1973. Factors affecting growth, sporulation, pathogenicity, and survival of Ascochyta rabiei. Mycologia 65:444-457.

Kasahara, K., Miyamoto, T., Fujimoto, T., Oguri, H., Tokiwano, T., Oikawa, H., Ebizuka, Y., and Fujii, I. 2010. Solanapyrone synthase, a possible Diels-Alderase and iterative type I polyketide synthase encoded in a biosynthetic gene cluster from Alternaria solani. ChemBioChem 11: 1245-1252.

Katayama, K., Kobayashi, T., Oikawa, H., Honma, M., and Ichihara, A. 1998. Enzymatic activity and partial purification of solanapyrone synthase: First enzyme catalyzing Diels-Alder reaction. Biochem. Biophys. Acta Protein Struct. Mol. Enzymol. 1384:387-395.

Kaur, S. 1995. Phytotoxicity of solanapyrones produced by the fungus Ascochyta rabiei and their possible role in blight of chickpea (Cicer arietinum). Plant Sci. 109:23-29.

Khaldi, N., and Wolfe, K. H. 2011. Evolutionary origins of the fumonisin secondary metabolite gene cluster in Fusarium verticillioides and Aspergillus niger. Int. J. Evol. Biol. 2011, Article ID 423821.

Kim, H. J., Ruszczycky, M. W., Choi, S.-H., Liu, Y.-N., and Liu, H.-W. 2011. Enzyme-catalysed [4+2] cycloaddition is a key step in the biosynthesis of spinosyn A. Nature 473:109-112.

Kim, T.-H., Kunz, H.-H., Bhattacharjee, S., Hauser, F., Park, J., Engineer, C., Liu, A., Ha, T., Parker, J. E., Gassmann, W., and Schroeder, J. I. 2012. Natural variation in small molecule-induced TIR-NB-LRR signaling induces root growth arrest via EDS1- and PAD4-complexed R protein VICTR in Arabidopsis. Plant Cell 24:5177-5192.

Latif, Z., Strange, R. N., Bilton, J., and Riazuddin, S. 1993. Production of the phytotoxins, solanapyrones $\mathrm{A}$ and $\mathrm{C}$ and cytochalasin $\mathrm{D}$ among nine isolates of Ascochyta rabiei. Plant Pathol. 42:172-180.

Lorang, J. M., Carkaci-Salli, N., and Wolpert, T. J. 2004. Identification and characterization of victorin sensitivity in Arabidopsis thaliana. Mol. Plant-Microbe Interact. 17:577-582.

Lorang, J., Kidarsa, T., Bradford, C. S., Gilbert, B., Curtis, M., Tzeng, S.-C., Maier, C. S., and Wolpert, T. J. 2012. Tricking the guard: Exploiting plant defense for disease susceptibility. Science 338: 659-662.

Masuda, D., Ishida, M., Yamaguchi, K., Yamaguchi, I., Kimura, M., and Nishiuchi, T. 2007. Phytotoxic effects of trichothecenes on the growth and morphology of Arabidopsis thaliana. J. Exp. Bot. 58: 1617-1626.

Matern, U., Strobel, G., and Shepard, J. 1978. Reaction to phytotoxins in a potato population derived from mesophyll protoplasts. Proc. Natl. Acad. Sci. U.S.A. 75:4935-4939.
Mizushina, Y., Kamisuki, S., Kasai, N., Shimazaki, N., Takemura, M., Asahara, H., Linn, S., Yoshida, S., Matsukage, A., Koiwai, O., Sugawara, F., Yoshida, H., and Sakaguchi, K. 2002. A plant phytotoxin, solanapyrone $\mathrm{A}$, is an inhibitor of DNA polymerase $\beta$ and $\lambda$. J. Biol. Chem. 277:630-638.

Möbius, N., and Hertweck, C. 2009. Fungal phytotoxins as mediators of virulence. Curr. Opin. Plant Biol. 12:390-398.

Mogensen, E. G., Challen, M. P., and Strange, R. N. 2006. Reduction in solanapyrone phytotoxin production by Ascochyta rabiei transformed with Agrobacterium tumefaciens. FEMS Microbiol. Lett. 255: 255-261.

Nene, Y. L. 1982. A review of Ascochyta blight of chickpea. Trop. Pest Manage. 28:61-70.

Nishiuchi, T., Masuda, D., Nakashita, H., Ichimura, K., Shinozaki, K., Yoshida, S., Kimura, M., Yamaguchi, I., and Yamaguchi, K. 2006. Fusarium phytotoxin trichothecenes have an elicitor-like activity in Arabidopsis thaliana, but the activity differed significantly among their molecular species. Mol. Plant-Microbe Interact. 19:512-520.

O’Reilly, E., Corbett, M., Hussain, S., Kelly, P. P., Richardson, D., Flitsch, S. L., and Turner, N. J. 2013. Substrate promiscuity of cytochrome P450 RhF. Catal. Sci. Tech. 3:1490-1492.

Oikawa, H., Kobayashi, T., Katayama, K., Suzuki, Y., and Ichihara, A. 1998a. Total synthesis of (-)-solanapyrone A via enzymatic Diels-Alder reaction of prosolanapyrone. J. Org. Chem. 63:8748-8756.

Oikawa, H., Yokota, T., Sakano, C., Suzuki, Y., Naya, A., and Ichihara, A. 1998b. Solanapyrones, phytotoxins produced by Alternaria solani: Biosynthesis and isolation of minor components. Biosci. Biotechnol. Biochem. 62:2016-2022.

Payne, G. A., Nystrom, G. J., Bhatnagar, D., Cleveland, T. E., and Woloshuk, C. P. 1993. Cloning of the afl-2 gene involved in aflatoxin biosynthesis from Aspergillus flavus. Appl. Environ. Microbiol. 59: 156-162.

Peever, T. L., Chen, W., Abdo, Z., and Kaiser, W. J. 2012. Genetics of virulence in Ascochyta rabiei. Plant Pathol. 61:754-760.

Peplow, A. W., Tag, A. G., Garifullina, G. F., and Beremand, M. N. 2003. Identification of new genes positively regulated by Tri10 and a regulatory network for trichothecene mycotoxin production. Appl. Environ. Microbiol. 69:2731-2736.

Rouxel, T., Grandaubert, J., Hane, J. K., Hoede, C., van de Wouw, A. P., Couloux, A., Dominguez, V., Anthouard, V., Bally, P., Bourras, S., Cozijnsen, A. J., Ciuffetti, L. M., Degrave, A., Dilmaghani, A., Duret, L. Fudal, I., Goodwin, S. B., Gout, L., Glaser, N., Linglin, J., Kema, G. H. J., Lapalu, N., Lawrence, C. B., May, K., Meyer, M., Ollivier, B., Poulain, J., Schoch, C. L., Simon, A., Spatafora, J. W., Stachowiak, A., Turgeon, B. G., Tyler, B. M., Vincent, D., Weissenbach, J., Amselem, J., Quesneville, H., Oliver, R. P., Wincker, P., Balesdent, M.-H., and Howlett, B. J. 2011. Effector diversification within compartments of the Leptosphaeria maculans genome affected by repeat-induced point mutations. Nat. Commun. 2011:202.

Roy, S., Singh, S. K., Choudhury, S. R., and Sengupta, D. N. 2009. An insight into the biological functions of family X-DNA polymerase in DNA replication and repair of plant genome. Plant Signal. Behav. 4: 678-681.

Santra, D. K., Tekeoglu, M., Ratnaparkhe, M., Kaiser, W. J., and Muehlbauer, F. J. 2000. Identification and mapping of QTLs conferring resistance to Ascochyta blight in chickpea. Crop Sci. 40:1606-1612.

Schmidt, L. E., Gloer, J. B., and Wicklow, D. T. 2007. Solanapyrone analogues from a Hawaiian fungicolous fungus. J. Nat. Prod. 70: 1317-1320.

Schmittgen, T. D., and Livak, K. J. 2008. Analyzing real-time PCR data by the comparative C(T) method. Nat. Protoc. 3:1101-1108.

Siewers, V., Viaud, M., Jimenez-Teja, D., Collado, I. G., Gronover, C. S., Pradier, J.-M., Tudzynski, B., and Tudzynski, P. 2005. Functional analysis of the cytochrome P450 monooxygenase gene bcbot1 of Botrytis cinerea indicates that botrydial is a strain-specific virulence factor. Mol. Plant-Microbe Interact. 18:602-612.

Singh, K. B., Reddy, M. V., and Nene, Y. L. 1984. International testing of chickpeas for resistance to Ascochyta blight. Plant Dis. 68:782-784.

Slot, J. C., and Rokas, A. 2011. Horizontal transfer of a large and highly toxic secondary metabolic gene cluster between fungi. Curr. Biol. 21: 134-139.

Song, J., Durrant, W. E., Wang, S., Yan, S., Tan, E. H., and Dong, X. 2011. DNA repair proteins are directly involved in regulation of gene expression during plant immune response. Cell Host Microbe 9:115-124.

Stone, J. M., Heard, J. E., Asai, T., and Ausubel, F. M. 2000. Simulation of fungal-mediated cell death by fumonisin B1 and selection of fumonisin B1-resistant (fbr) Arabidopsis mutants. Plant Cell 12: 1811-1822. 
Trisuwan, K., Rukachaisirikul, V., Sukpondma, Y., Preedanon, S., Phongpaichit, S., and Sakayaroj, J. 2009. Pyrone derivatives from the marine-derived fungus Nigrospora sp. PSU-F18. Phytochemistry 70: 554-557.

Tsuge, T., Harimoto, Y., Akimitsu, K., Ohtani, K., Kodama, M., Akagi, Y., Egusa, M., Yamamoto, M., and Otani, H. 2013. Host-selective toxins produced by the plant pathogenic fungus Alternaria alternata. FEMS Microbiol. Rev. 37:44-66.

Turgeon, B. G., and Lu, S.-W. 2000. Evolution of host specific virulence in Cochliobolus heterostrophus. Pages 93-126 in: Fungal Pathology. N. S., Iacobellis, A. Collmer, S. W. Hutcheson, J. W. Mansfield, C. E. Morris, J. Murillo, N. W. Schaad, D. E. Stead, G. Surico, and M. Ullrich, eds. Kluwer Academic Publishers, Dordrecht, The Netherlands.

Vail, S., and Banniza, S. 2008. Structure and pathogenic variability in Ascochyta rabiei populations on chickpea in the Canadian prairies. Plant Pathol. 57:665-673.

Walton, J. D. 1996. Host-selective toxins: Agents of compatibility. Plant Cell 8:1723-1733.

Wang, S., Durrant, W. E., Song, J., Spivey, N. W., and Dong, X. 2010. Arabidopsis BRCA2 and RAD51 proteins are specifically involved in defense gene transcription during plant immune responses. Proc. Natl. Acad. Sci. U.S.A. 107:22716-22721.
Waring, P., Eichner, R. D., Müllbacher, A., and Sjaarda, A. 1988. Gliotoxin induces apoptosis in macrophages unrelated to its antiphagocytic properties. J. Biol. Chem. 263:18493-18499.

Wilson, A. D., and Kaiser, W. J. 1995. Cytology and genetics of sexual incompatibility in Didymella rabiei. Mycologia 87:795-804.

Wu, S. H., Chen, Y. W., Shao, S. C., Wang, L. D., Yu, Y., Li, Z. Y., Yang, L. Y., Li, S. L., and Huang, R. 2009. Two new solanapyrone analogues from the endophytic fungus Nigrospora sp. YB-141 of Azadirachta indica. Chem. Biodivers. 6:79-85.

Wu, D., Oide, S., Zhang, N., Choi, M. Y., and Turgeon, B. G. 2012. ChLae1 and ChVel1 regulate T-toxin production, virulence, oxidative stress response, and development of the maize pathogen Cochliobolus heterostrophus. PLoS Pathog. 8:e1002542.

Yamtich, J., and Sweasy, J. B. 2010. DNA polymerase family X: Function, structure, and cellular roles. Biochim. Biophys. Acta Proteins Proteomics 1804:1136-1150.

Yoder, O. C. 1973. A selective toxin produced by Phyllosticta maydis. Phytopathology 63:1361-1366.

Yu, J.-H., Hamari, Z., Han, K.-H., Seo, J.-A., Reyes-Domínguez, Y., and Scazzocchio, C. 2004. Double-joint PCR: A PCR-based molecular tool for gene manipulations in filamentous fungi. Fungal Genet. Biol. 41: 973-981. 